\title{
Kinases of eIF2a Switch Translation of mRNA Subset during Neuronal Plasticity
}

\author{
Ekaterina Chesnokova *, Natalia Bal and Peter Kolosov* \\ Cellular Neurobiology of Learning Lab, Institute of Higher Nervous Activity and Neurophysiology, \\ Russian Academy of Sciences, Moscow 117485, Russia; admin@ihna.ru \\ * Correspondence: chesnokova@ihna.ru (E.C.); kolosov@ihna.ru (P.K.)
}

Received: 29 September 2017; Accepted: 19 October 2017; Published: 22 October 2017

\begin{abstract}
Compared to other types of cells, neurons express the largest number of diverse mRNAs, including neuron-specific ones. This mRNA diversity is required for neuronal function, memory storage, maintenance and retrieval. Regulation of translation in neurons is very complicated and involves various proteins. Some proteins, implementing translational control in other cell types, are used by neurons for synaptic plasticity. In this review, we discuss the neuron-specific activity of four kinases: protein kinase R (PKR), PKR-like endoplasmic reticulum kinase (PERK), general control nonderepressible 2 kinase (GCN2), and heme-reguated eIF2 $\alpha$ kinase (HRI), the substrate for which is $\alpha$-subunit of eukaryotic initiation factor 2 (eIF2 $\alpha$ ). Phosphorylation of eIF2 $\alpha$ is necessary for the cell during stress conditions, such as lack of amino acids, energy stress or viral infection. We propose that, during memory formation, neurons use some mechanisms similar to those involved in the cellular stress. The four eIF $2 \alpha$ kinases regulate translation of certain mRNAs containing upstream open reading frames (uORFs). These mRNAs encode proteins involved in the processes of long-term potentiation (LTP) or long-term depression (LTD). The review examines some neuronal proteins for which translation regulation by eIF2 was suggested and checked experimentally. Of such proteins, we pay close attention to protein kinase $\mathrm{M} \zeta$, which is involved in memory storage and regulated at the translational level.
\end{abstract}

Keywords: eIF2; eIF2 $\alpha$ kinases; 5'-UTR; uORFs; neuronal plasticity; PKM $\zeta$; cell stress; neuronal pathologies

\section{Neuron-Specific Translation Initiation Regulation and the Role of Kinases Phosphorylating $\alpha$-Subunit of Eukaryotic Initiation Factor 2 (eIF2 $\alpha$ ) in This Process}

\subsection{Neuronal Plasticity and Translation}

Activation of different membrane receptors affects local de novo protein synthesis and causes changes at the proteome level in postsynaptic terminals. Synthesis of new proteins in these terminals requires the presence of an autonomous translation apparatus that is almost independent of the processes going on in neuronal soma. Certain mRNAs, pre-transported from the nucleus and "conserved" for long-term storage, as well as ribosomes and translational factors, should be present in the dendrites to quickly start the translation of target proteins in synapses. Regulation of this local translation, as well as its correlation with somatic translation processes, may be quite complex. For example, it was shown that activation of neurons by the neurotrophic factor brain-derived neurotropic factor (BDNF) leads to an augmentation of translation in postsynaptic regions but suppresses protein translation in the cell body. At the same time, administration of $\mathrm{N}$-methyl-D-aspartate (NMDA), a synthetic agonist of ionotropic glutamate receptors, to synaptoneurosomes, causes a selective increase in the synthesis of the $\alpha$-subunit of kinase $\mathrm{Ca}^{2+} /$ calmodulin-dependent protein kinase II (CaMKII) that contrasts with a simultaneous decrease 
in the total translation level. So, complex changes in translation, caused by activation of some membrane receptors, usually are at least bidirectional, and for many kinds of receptors such changes are still the issue for future studies [1]. However, a common feature of almost all mechanisms of translational regulation in neurons is the constitutive suppression of protein synthesis, which is alleviated only under strictly defined conditions, normally as a result of postsynaptic receptors activation. Dysfunction of these mechanisms, which causes excessive synthesis of neuronal proteins, often leads to pathologies, such as hyperexcitability of cells and epileptiform activity [2], or protein aggregation and neurodegeneration [3,4]. Suppression of local protein synthesis at rest allows the quick start of translation in the case of synaptic activation and depends on several factors. Arguably, the majority of translation regulation mechanisms are processes occurring at the initiation stage. One of the most important factors affecting initiation is the function of kinases. These kinases can phosphorylate translation factors and alter their activity, leading eventually to significant changes in the whole proteome of the cell.

\subsection{Eukaryotic Initiation Factor 2 (eIF2) and Four Kinases of Its $\alpha$-Subunit}

Eukaryotic initiation factor 2 (eIF2) is arguably the most important initiation factor involved in neuron-specific translation regulation. It is the main part of the initiation ternary complex (eIF2-Met-tRNAi-GTP) and one of the key translation rate regulators in the cell [5]. Phosphorylation of the $\alpha$-subunit of eIF2 arrests translation initiation. This phosphorylation can be accomplished by one of four kinases: PKR, HRI, GCN2 or PERK, all of which target Ser51 in eIF2 $\alpha$ [6]. All these kinases have different domain structures, and the only domain common for all four is the catalytic domain (Figure 1). All eIF2 $\alpha$ kinases are supposed to be activated by homodimerization and autophosphorylation [7-9]. Basically, GCN2 (general control nonderepressible 2) kinase is activated in response to amino acid deficiency, PERK (PKR-like endoplasmic reticulum kinase) responds to endoplasmic reticulum stress, HRI (heme-regulated eIF2 $\alpha$ kinase) is activated by heme deprivation in erythroid cells, and PKR (protein kinase R) participates in an antiviral defense pathway involving interferon [7]. Interestingly, there is some data indicating that the function of eIF $2 \alpha$ kinases is not limited to their kinase activity: PERK and PKR can also regulate the expression of specific proteins (such as cyclin D1 and tumor suppressor p53) by promoting their degradation in proteasomes [10].

\subsubsection{Kinase General Control Nonderepressible 2 (GCN2)}

GCN2 is the primary responder to nutritional deprivation and the only eIF2 $\alpha$ kinase conserved among virtually all eukaryotes [7]. GCN2 has the most complicated structure among four eIF2 $\alpha$ kinases. Besides a typical eukaryotic kinase domain, it also harbors a pseudo-kinase domain and a histidyl-tRNA synthetase (HisRS)-related domain [7,9]. The mechanism of GCN2 activation during amino acid depletion involves the binding of uncharged tRNAs in the cytoplasm to the HisRS-related domain of GCN2. Notably, activation of GCN2 occurs not only as a result of histidine starvation, but after deficit of some other amino acids as well, and also by various disruptions of aminoacyl-tRNA synthesis or amino acids turnover [7]. Moreover, GCN2 can also be activated by such stresses as viral infection, proteasome inhibition and UV irradiation [9]. tRNA after binding to GCN2 triggers a conformational change of the kinase molecule that results in autophosphorylation and autoactivation of GCN2 [7]. Mice with knocked-out GCN2 show sensitivity to nutritional deficiencies and aberrant eating behaviors [11]. GCN2 is also the predominant eIF2 $\alpha$ kinase expressed in the brain [12]. 


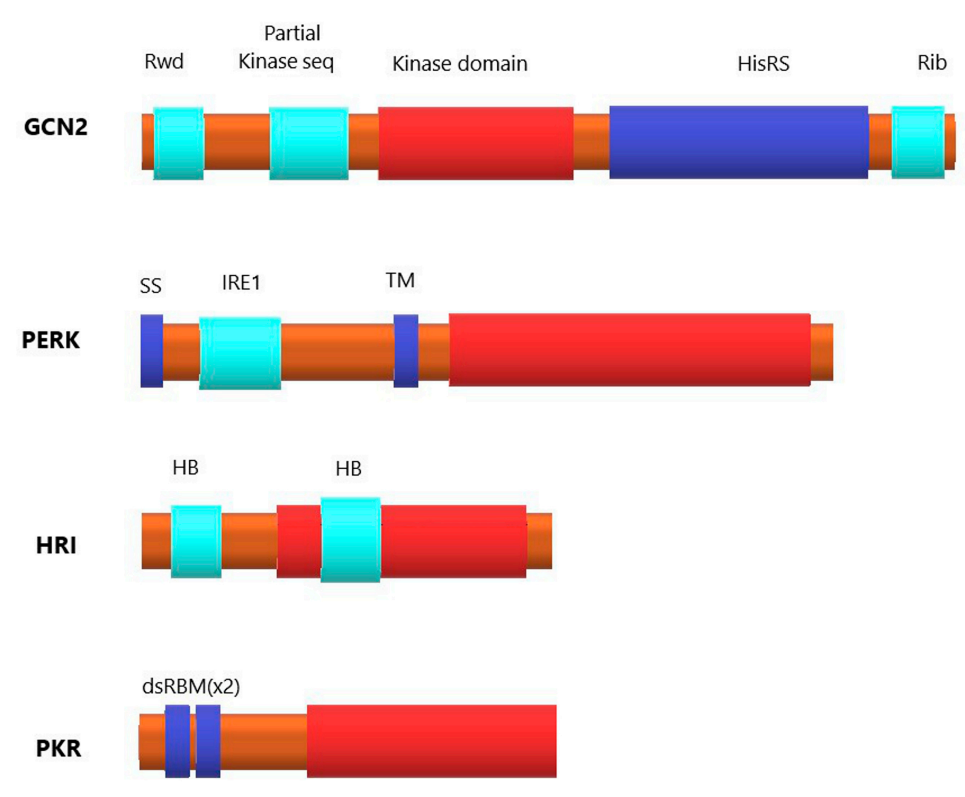

Figure 1. Domain structure of four kinases targeting $\alpha$-subunit of eukaryotic initiation factor 2. The catalytic domain (red) is present in all four kinases. General control nonderepressible 2 (GCN2): the RWD sequence (domain in RING finger and WD repeat containing proteins and DEXDc-like helicases) associates with the activator protein GCN1 (general control of amino-acid synthesis 1-like protein 1), partial kinase domain is a cis-regulatory element, the HisRS (histidyl-tRNA synthetase)-related sequence binds with uncharged tRNA, and the C-terminal region facilitates GCN2 dimerization and its ribosome association. PKR-like endoplasmic reticulum kinase (PERK): the signal sequence (SS) facilitates translocation of N-part of kinase into the lumen of endoplasmic reticulum, the IRE1 (inositol-requiring enzyme 1)-related sequence is the unfolded protein response sensor, TM is the transmembrane segment. Heme-regulated eIF2 $\alpha$ kinase (HRI): the molecule contains two heme-binding regions, one of which is inserted into the catalytic domain. Protein kinase R (PKR): two dsRBM motifs interact with double-stranded RNA.

\subsubsection{PKR-like Endoplasmic Reticulum Kinase (PERK)}

PERK is an endoplasmic reticulum (ER) transmembrane protein, and its regulatory region is situated in the lumen of the ER, while the eIF $2 \alpha$ kinase domain is protruded into the cytoplasm. Accumulation of misfolded proteins inside ER, that may be caused by calcium dysregulation, oxidative damage, nutritional deficits among other reasons, results in the complicated combination of processes within ER known as unfolded protein response (UPR), a variant of ER stress. This response includes translation shift via PERK phosphorylation of eIF2 $\alpha$, which reduces the overall transcription rate and thus decreases the influx of nascent proteins into the ER, along with activating a program of gene expression designed to expand the processing capacity of the ER and to enhance ER-associated protein degradation. The UPR is important in the pathogenesis of many diseases, including diabetes, renal disorders, neuropathologies, and cancer. Misfolded proteins that accumulate in the ER lumen during ER stress are suggested to provoke the dissociation of PERK from the ER chaperone BiP/GPR78, thus leading to PERK oligomerization, which facilitates PERK autophosphorylation and autoactivation [7]. Intriguingly, a mechanism of PERK activation in the absence of misfolded proteins and without changes in the expression of ER chaperones after ischemia in the brain was described, suggesting more complex and nuanced control of PERK signaling, which may be mediated through changes in ATP or $\mathrm{Ca}^{2+}$ levels within the ER, which are in turn sensed by BiP or co-chaperone. Indeed, $\mathrm{Ca}^{2+}$ and calmodulin-dependent phosphatase calcineurin was identified as a direct modifier of PERK activity. In mice, deletion of PERK leads to neonatal insulin-dependent diabetes, epiphyseal dysplasia, hepatic and renal complications [11]. Loss-of-function mutation of PERK is the cause of 
Wolcott-Rallison syndrome in humans, a disease characterized by neonatal onset of diabetes, as well as defects in the pancreas and in the skeletal system [9]. In regard to the neuronal function of PERK, recent studies suppose that it may be one of the key proteins involved in memory impairments and neurodegeneration in Alzheimer's disease. It was also implicated that PERK dysregulation is important in the pathogenesis of other neurodegenerative disorders, such as Parkinson's disease, Huntington's disease, amyotrophic lateral sclerosis and frontotemporal dementia [6]. Some data also indicate that alterations of normal PERK function are connected with aging-related deterioration processes in neurons, as was shown in the study of retinal cells of aged rats [13].

\subsubsection{Heme-regulated eIF2 $\alpha$ kinase (HRI)}

HRI plays an important role in erythroid cells. It contains two regions that can bind to heme, one at the N-terminal and the second within the kinase domain. Heme binding represses kinase activity, so a reduced amount of heme in erythroid cells triggers HRI activation [7]. Besides heme, both nitric oxide $(\mathrm{NO})$ and carbon monoxide $(\mathrm{CO})$ can bind to the N-terminal heme-binding domain of HRI [8]. NO acts as an activator of HRI [8,14,15], while CO serves as a suppressor of NO-induced HRI activation [8]. It was initially thought that HRI expression is limited to erythrocytes, but then it was demonstrated that it is also present in the liver and in macrophages [9]. Importantly, in the recent study, HRI was also found in neurons and confirmed to be important for memory consolidation [14].

\subsubsection{Protein Kinase R (PKR)}

PKR is only conserved in vertebrates and it is not found in plants, fungi, protists, and invertebrates [8]. PKR was initially discovered as a kinase that phosphorylates eIF $2 \alpha$ in response to viral infection, thereby blocking the translation of viral mRNAs and promoting apoptosis in response to viral infection. However, PKR can also be activated in response to other diverse signals, such as oxidative and ER stress, cytokine signaling and growth factors. This kinase has been implicated in the pathogenesis of obesity and cancer. The structure and the mechanism of activation of PKR are the best characterized among four eIF $2 \alpha$ kinases. PKR is localized in the cytosol and the nucleus. Its regulatory N-terminal region contains a double-stranded RNA binding domain that inhibits the catalytic domain in the absence of ds-RNA. The C-terminal catalytic domain has a dimerization site. Another important regulator of PKR besides dsRNA is PACT (Protein Activator), which becomes phosphorylated in response to various stress factors. PKR has many targets besides eIF2 $\alpha$. It phosphorylates p53, indirectly facilitates activation of the STAT transcription factors, promotes MAPK activity, induces expression of the pro-apoptotic transcription factor CHOP (CCAAT-Enhancer-binding protein Homologous Protein) and mediates NF- $\mathrm{kB}$ activation. In general, the role of PKR in response to ER stress seems to be in direct opposition to that of PERK: activation of PKR eventually leads to apoptosis (but not always) [9].

\subsection{The Mechanism of Translation Shift Caused by eIF2 $\alpha$ Phosphorylation and Its Role in Neurons}

Activation of kinases phosphorylating eIF2 $\alpha$ suppresses general translation, but also selectively stimulates the translation of some specific mRNAs. Typically, these mRNAs have long $5^{\prime}$-UTR with complicated secondary structure and a few short upstream open reading frames (uORFs) providing multiple "false starts" of translation initiation and thus hampering the initiation on the main frame. All these features mean that initiation of translation from such mRNAs is consistently low, the rate-limiting stage of their translation is not initiation but elongation, and so they thrive when eIF2 $\alpha$ is phosphorylated and initiation of other mRNAs is suppressed [16]. Most of such proteins participate in cell stress response, and particularly in ER stress [17-23].

Global effects of eIF $2 \alpha$ phosphorylation during cell stress are, first, conservation of energetic resources achieved by decrement of total translation and, second, outbreak of proteins necessary for the repair of stress-caused damage- or for induction of apoptosis. Some of these proteins are regulated transcriptionally, while p-eIF $2 \alpha$ controls the level of correspondent transcription factors. 
Thus, eIF2 $\alpha$ phosphorylation results in increased translation of transcription factors ATF4, ATF5, ATF6, XBP-1 and CHOP which, in turn, selectively induce the transcription of multiple genes coding for ER chaperones and enzymes needed to cope with the excess of unfolded proteins in the ER or trigger apoptosis. Other proteins important for overcoming cell stress, such as VEGF-A (angiogenic factor that is important for compensation of chronic hypoxia effects) or GADD34 (necessary for p-eIF2 $\alpha$ dephosphorylation and reversal of stress-caused changes) are believed to be upregulated by p-eIF $2 \alpha$ directly at the translational level [23].

However, there is much data indicating that in neurons, p-eIF2 $\alpha$-driven translational shift is a necessary part of normal neuronal function in the absence of stress. eIF2 is an important regulator of synaptic plasticity (noteworthy, some of p-eIF $2 \alpha$ downstream proteins are important for both stress response and neuronal plasticity) [23-29].

Considering the dual role of p-eIF $2 \alpha$ in neuronal cells, we will discuss below its role in both stressed and normally functioning neurons, but will focus on the latter. It must also be noted that in some works reporting some aspects of eIF2 role in synaptic plasticity and memory, the methods used were in fact in vitro or in vivo models of some pathological conditions [30,31], so the neurons examined in these works most likely endured cellular stress, and it is hard to discriminate the role of eIF2 in stress signaling from its neuron-specific function by analyzing these results (one paper [32] is a rare example of work in which the authors actually checked if the changes they observed in neurons were caused by cellular stress).

\section{Neuron-Specific Proteins that May Be Regulated by eIF2 $\alpha$ Phosphorylation}

The list of proteins that have three things in common-first, it is known that their mRNAs contain uORFs in their $5^{\prime}$-UTR; second, expression of their mRNAs in neurons was established; and third, regulation of their translation in neurons via eIF2-related mechanisms was proposed-is presented in Table 1. 
Table 1. Upstream open reading frames (uORF)-containing mRNAs that code proteins important for neuronal function, and their regulation by kinases of $\alpha$-subunit of eukaryotic initiation factor 2 (eIF2 $\alpha$ ).

\begin{tabular}{|c|c|c|c|}
\hline Protein Name & Protein Function & $\begin{array}{c}\text { The Number of uORFs and Presence of } \\
\text { Other Translation-Impeding Features in } \\
\text { mRNA } 5^{\prime} \text {-UTR }\end{array}$ & $\begin{array}{c}\text { eIF2 } \alpha \text { Kinases that May be Involved in mRNA } \\
\text { Translation Regulation }\end{array}$ \\
\hline $\begin{array}{l}\text { Activating transcription factor } 4 \text { (ATF4), } \\
\text { also known as cAMP-response element binding } \\
\text { protein } 2 \text { (CREB-2) }\end{array}$ & transcription repressor & 2 uORFs, uORF2 overlaps with the main frame & $\begin{array}{c}\text { General control nonderepressible } 2 \\
\text { (GCN2) }[12,31] \\
\text { PKR-like endoplasmic reticulum kinase } \\
\text { (PERK) }[29,31]\end{array}$ \\
\hline $\begin{array}{l}\text { Growth arrest and DNA damage-inducible } \\
\text { protein (GADD34), } \\
\text { also known as protein phosphatase regulatory } \\
\text { subunit 15A (PPP1R15A) }\end{array}$ & $\begin{array}{l}\text { regulatory subunit of p-eIF2 } \alpha \\
\text { phosphatase, activated by } \\
\text { DNA lesion }\end{array}$ & $2 \mathrm{uORFs}$ & $\begin{array}{l}\text { GCN2 and PERK [20] *, Protein kinase R } \\
\text { (PKR) [21] * }\end{array}$ \\
\hline $\begin{array}{l}\text { CCAAT-enhancer-binding protein homologous } \\
\text { protein (CHOP), } \\
\text { also known as DNA damage-inducible transcript } \\
\text { 3 (DDIT3) }\end{array}$ & $\begin{array}{l}\text { transcription repressor, activated } \\
\text { by DNA lesion }\end{array}$ & $\begin{array}{c}3 \mathrm{uORFs} \text {; the short peptide translated from uORF2 } \\
\text { is important for the repression of the main frame } \\
\text { translation [33] }\end{array}$ & $\begin{array}{l}\text { Presumably not PERK [31] } \\
\text { GCN2 [22] * }\end{array}$ \\
\hline Beta-site APP-cleaving enzyme 1 (BACE1) & $\begin{array}{l}\text { protease, most known for its role } \\
\text { in } \beta \text {-amyloid production }\end{array}$ & 4 uORFs, complicated secondary structure & $\begin{array}{c}\text { PERK [30] } \\
\text { Heme-regulated eIF2 } \alpha \text { kinase (HRI) [14] }\end{array}$ \\
\hline $\begin{array}{c}\text { Glutamate ionotropic receptor NMDA type } \\
\text { subunit 2B (GluN2B) }\end{array}$ & $\begin{array}{c}\text { ionotropic glutamate receptor } \\
\text { subunit }\end{array}$ & $3 \mathrm{uORFs}$ & HRI [15] \\
\hline Oligophrenin-1 & Rho-GTPase-activating protein & $2 \mathrm{uORFs}$ & PKR [28] \\
\hline $\begin{array}{l}\text { Synapse-Associated Protein 90/Postsynaptic } \\
\text { Density Protein-95-Associated Protein } 3 \text { (SAPAP3) }\end{array}$ & $\begin{array}{l}\text { scaffolding protein of the } \\
\text { postsynaptic density }\end{array}$ & $\begin{array}{c}4 \text { uORFs, high GC content; uORF2 is also } \\
\text { important for translation start shift between } \\
2 \text { distinct start codons in protein-coding frame [34] }\end{array}$ & No data \\
\hline $\begin{array}{c}\text { SH3 and multiple ankyrin repeat domains } \\
1 \text { (Shank1) }\end{array}$ & $\begin{array}{l}\text { scaffolding protein of the } \\
\text { postsynaptic density }\end{array}$ & $\begin{array}{l}3 \text { conventional uORFs (uORF3 overlaps with the } \\
\text { main frame) and the fourth unique uORF that } \\
\text { starts with non-canonical start codon ACG and } \\
\text { upregulates main frame translation }\end{array}$ & $\begin{array}{l}\text { eIF2 } \alpha \text { phosphorylation is not important for } \\
\text { regulation of this mRNA translation [35] }\end{array}$ \\
\hline Neuron-specific BCL2-antagonist/killer (N-Bak) & pro-apoptotic factor & $\begin{array}{l}1 \text { or } 2 \text { uORFs in different species; also, } 3^{\prime} \text {-UTR of } \\
\text { N-Bak contains premature termination codon and } \\
\text { exon-exon junction }\end{array}$ & $\begin{array}{l}\text { eIF2 } \alpha \text { phosphorylation is not important for } \\
\text { regulation of this mRNA translation; it was } \\
\text { demonstrated that N-Bak mRNA translation is } \\
\text { repressed consistently, even during apoptosis [36] }\end{array}$ \\
\hline Protein kinase $\mathbf{M} \zeta(\mathbf{P K M} \zeta)$ & $\begin{array}{l}\text { kinase, known for its importance } \\
\text { in memory formation }\end{array}$ & $\begin{array}{l}7 \mathrm{uORFs} \text { (unusually many, supposedly each of } \\
\text { them contributes to the translation repression) [37] }\end{array}$ & PERK [31] \\
\hline
\end{tabular}

* These data were obtained in experiments addressing cell stress and performed on various non-neuronal cells. 


\subsection{Activating Transcription Factor 4 (ATF4)}

Presumably the most important protein that is known to be regulated translationally by phosphorylation of eIF $2 \alpha$ and associated both with cell stress and neuronal activity is activating transcription factor 4 (ATF4), also known as cAMP-response element binding protein 2 (CREB-2) [12,18-20,38]. ATF4, despite its name, is a highly conserved repressor of CREB-mediated gene expression, and ATF4-mediated transcription block must be released for the late phase of long-term potentiation (L-LTP) and formation of long-term memory [39,40].

The 5'-UTR of ATF4 mRNA contains two uORFs, conserved from invertebrates to mammals [41]. The first uORF is very short, and most of scanning ribosomes reinitiate at uORF2 after termination of uORF1 translation. The second uORF overlaps with the first 83 nucleotides of the main reading frame. If there are many ternary complexes available, a large fraction of scanning ribosomes initiate on the uORF2, thus terminating downstream of the ATF4 major initiation codon. Ribosomes cannot scan backwards, so translation from the main reading frame is low. In contrast, when eIF $2 \alpha$ is phosphorylated, the number of ternary complexes is reduced, and many of the scanning 40S subunits cannot initiate on the second uORF, thus bypassing it, sliding further, and continue scanning, which makes translation initiation at the major ATF4 start codon more likely [27].

In research by Jiang et al. [29], a conditional transgenic mouse strain was generated, in which PKR-mediated phosphorylation of eIF2 $\alpha$ was specifically increased in hippocampal CA1 pyramidal cells by the chemical inducer. Administration of this inducer significantly increased translation of ATF4 (with no obvious reduction in general translation), and this led to suppression of CREB-dependent pathways in CA1 cells, impairment of hippocampal late-phase LTP and memory consolidation, as was shown in electrophysiological experiments with hippocampal slices and in behavioral experiments with contextual fear conditioning. At the same time, inhibition of general translation by low-dose anisomycin did not block hippocampal-dependent memory consolidation [29].

Despite the established role of ATF4 as a suppressor of synaptic plasticity, it cannot be said that a constitutive decrease of ATF4 concentration in neurons enhances L-LTP and promotes memory formation, since the changes are more complicated and, in some respect, bidirectional, as was shown in experiments with GCN2 ${ }^{-/-}$mice. These mice have a decreased eIF2 $\alpha$ phosphorylation level and decreased concentration of ATF4 in their hippocampal neurons, as was demonstrated by Western blotting. In hippocampal slices from these mice, a single 100-Hz train in CA1, that is not enough for L-LTP formation in wild-type mice, induced a strong and sustained L-LTP. In contrast, electrical or chemical stimulation variants that normally elicit L-LTP in wild-type slices, failed to evoke L-LTP in $\mathrm{GCN}^{-/-}$slices. Somewhat similar results were obtained in behavioral tests in vivo (Morris water maze): after weak training (once a day), the spatial memory of mutant mice was improved compared to wild-type control, but it was impaired after more intense training (three times a day). In some sense, the absence of ATF4 block makes neurons over-sensitive to stimulation, and their potentiation occurs "too easy". So, neuronal activity-dependent shifts in ATF4 level, caused by GCN2 activity, are important for long-term potentiation to occur normally [12].

In another work concerning ATF4, APP/PS1 mice (double transgenic mice expressing a chimeric mouse/human amyloid precursor protein and a mutant human presenilin 1 in their neurons), an established animal model of Alzheimer's disease, was used. First, the authors confirmed the increase of ATF4 translation and the elevated eIF2 $\alpha$ phosphorylation level in hippocampi of APP/PS1 mice (compared to wild-type mice) by Western blotting. Next, using the Cre-loxP technique, additionally genetically modified mice were bred, APP/PS1, in which PERK was conditionally removed in excitatory neurons in the forebrain and hippocampus late in development. The genetic deletion of PERK prevented enhanced eIF $2 \alpha$ phosphorylation, caused an increase in the overall translation level and selective suppression of ATF4, and rescued impairment of synaptic plasticity (high-frequency stimulation of acute hippocampal slices was used to assess LTP formation) and spatial memory (estimated by Morris water maze, $\mathrm{Y}$ water maze and object location test), in these mice. Mice from another mutant line, APP/PS1 with constitutive deletion of GCN2, also demonstrated improved 
synaptic plasticity and spatial learning compared to APP/PS1, but GCN2 knockout did not decrease the basal eIF2 $\alpha$ phosphorylation level as drastically as PERK knockout (in APP/PS1 mice with PERK knockout, eIF $2 \alpha$ phosphorylation was even lower than in wild-type animals). So, the authors supposed that PERK may be more important for eIF2 regulation than GCN2 [31].

\subsection{ER Stress-Related Proteins: Growth Arrest and DNA Damage-Inducible Protein (GADD34) and CCAAT-Enhancer-Binding Protein Homologous Protein (CHOP)}

CHOP and GADD34 proteins participate in the same signaling pathways as ATF4 and, being structurally unrelated, have much in common in their regulation and function. Both CHOP and GADD34 are connected with ER stress response. The expression of both these proteins is regulated by ATF4 [20,38], and it was also demonstrated that CHOP can directly activate GADD34 [42].

In the work by Biever et al. [32], mice were repeatedly administered with D-amphetamine (systemic injection), and then overall translation changes in their striatum were observed by polysome profile analysis on striatal lysates, and differential expression of selected genes was assessed by RT-qPCR. In this particular work, direct molecular targets of amphetamine in neurons were not discussed, but it is well known that this drug increases the concentration of catecholamines in the synaptic cleft by several distinct mechanisms (see [43] for review). Polysome profiling of striata of amphetamine-treated mice showed an increase in the amplitude of the "vacant" 805 monosome peak along with a reduction in the polysome population (compared to saline-treated mice). It means that amphetamine causes a decrease of global mRNA translation in the striatum. This result was confirmed in another experiment, in which lysates were treated with puromycin, an antibiotic that binds selectively to nascent protein chains and allows to measure de novo protein synthesis level. A puromycin-based assay demonstrated that the overall protein synthesis level in striatal ribosomes was decreased in amphetamine-treated mice. Using Western blotting analysis of whole striatal lysates at different time points, the authors also confirmed a robust enhancement of phosphorylated eIF $2 \alpha$, most prominent at $30 \mathrm{~min}$ after amphetamine injection. The targets selected for RT-qPCR were several mRNAs known to contain uORFs in their 5'-UTR. Two studied uORF-bearing mRNAs, GADD34 and $\mathrm{CHOP}$, were found to be enriched in polysomal fractions of amphetamine-treated mice, indicating that the translation of these mRNAs was upregulated. (Unexpectedly, ATF4 translation was unchanged after amphetamine administration.) While GADD34 mRNA was also enriched in non-polysomal fractions, suggesting that GADD34 was enhanced not only translationally but also transcriptionally, CHOP mRNA was only enriched in polysomal fractions.

GADD34 (growth arrest and DNA damage-inducible protein) is also known as PPP1R15A (protein phosphatase regulatory subunit 15A). It plays an important role in recovery from endoplasmatic reticulum stress because it dephosphorylates p-eIF2 $\alpha$ and thus reactivates normal protein synthesis. In neurons, the function of this protein is associated with the recovery from ischemia [44]. Considering that GADD34 is both a protein activated by p-eIF2 $\alpha$ and a necessary factor for p-eIF $2 \alpha$ dephosphorylation, it provides a negative feedback loop, preventing uncontrollable p-eIF $2 \alpha$ accumulation and stress-related decompensation processes in the cell. It should also be noticed that proper GADD34 function requires the presence of monomeric G-actin [45,46]. Mouse GADD34 mRNA contains two overlapping and out of frame uORFs [47,48]. CHOP (CCAAT-enhancer-binding protein homologous protein) is also known as DDIT3 (DNA damage-inducible transcript 3), and is a transcription inhibitor important for ER stress response and apoptosis induction. CHOP apparently has no specific role in normally functioning neurons, as it is known to be upregulated in neurons only in different stress conditions $[49,50]$. CHOP-mediated apoptosis may be involved in the development of Parkinson's disease, polyglutamine disease [51] and amyotrophic lateral sclerosis [52]. The $5^{\prime}$-UTR of human CHOP mRNA contains three uORFs, but only the second one of them is not in-frame with the leader sequence and is highly conserved between human, mouse and hamster. Experiments with genetic constructs containing wild-type or mutated CHOP mRNA 5'-UTR and luciferase reporter showed that this uORF inhibits translation from the main reading frame. Further changes in this 
construct, including different mutations that had a small effect on mRNA structure but drastically changed the sequence of the uORF-encoded short peptide, demonstrated that this peptide itself is partly responsible for the repression of main frame transcription. In HeLa cells expressing constructs with upstream start codon in place, but peptide-altering mutation within the upstream reading frame, the level of reporter was higher than in cells expressing constructs with wild-type $5^{\prime}$-UTR but still lower than in cells expressing constructs with $5^{\prime}$-UTR without upstream start codon [33].

Considering that both proteins that were shown to be translationally up-regulated by systemic amphetamine administration are important for ER stress response, the authors specifically tested if an eIF $2 \alpha$-mediated translation shift in neurons was caused by cellular stress mechanisms. They measured the levels of some proteins that are known as markers for ER stress (this list included PERK), and also markers of apoptosis and gliosis, in striatal lysates of experimental animals. It was shown that striatal levels of almost all evaluated markers were not altered by amphetamine, indicating that amphetamine exposure was not accompanied by ER stress or neurotoxicity. It allowed the authors to conclude that the regulation of translation by D-amphetamine most likely contributes to persistent modifications altering striatal plasticity rather than representing a protective mechanism to cope with an insult [32]. Biever et al. registered eIF2 $\alpha$ phosphorylation increase correlating with GADD34 and CHOP expression increase, but did not identify which of the four eIF $2 \alpha$ kinases was responsible for this effect. However, in another work, it was demonstrated that cell stress-dependent translation of GADD34 is partially suppressed in $P E R K^{-/-}$cultured CHO-K1 cells and almost completely suppressed in $\mathrm{GCN}^{-/-}$cells [20], so supposedly both these kinases participate in GADD34 regulation; GCN2 is more important for this, and there still may exist some alternative pathways for GADD34 expression activation bypassing both these kinases (and maybe even completely independent of eIF2 $\alpha$ phosphorylation). This third proposal is confirmed, for example, by the fact that in specific conditions (viral infection), GADD34 in fibroblasts is activated via PKR kinase [21].

As for CHOP, in the described above work with an Alzheimer's disease animal model, CHOP concentration was found to be unaltered in APP/PS1 mice with conditional PERK knock-out compared to APP/PS1 mice [31], so we may speculate that PERK is not important for CHOP translation regulation. Consistent with this, $\mathrm{CHOP}$ upregulation after chemically induced stress in mouse embryonic fibroblasts was proved to be caused by GCN2 [22].

\subsection{Beta-Site APP-Cleaving Enzyme 1 (BACE1), the Enzyme Connected with Alzheimer's Disease}

The role of eIF2 in Alzheimer's disease was already mentioned above in regard to ATF4 translation regulation [31]. However, ATF4 is not the only protein for which translation is regulated by an eIF2-dependent mechanism that becomes disrupted in Alzheimer's disease. Beta-site APP-cleaving enzyme 1 (BACE1) is the rate-limiting enzyme for $\beta$-amyloid production. BACE1 concentration increase is typical for Alzheimer's disease. It is known that BACE1 mRNA 5'-UTR is a cis-acting translational repressor because it is long, GC-rich, has a complicated secondary structure, and contains four uORFs [14].

In the research addressing eIF2-mediated translation regulation of BACE1, glucose starvation was used as a model of cell stress [30]. There is some data indicating that BACE1 increase in Alzheimer's disease might be a result of translational derepression of the BACE1 mRNA 5'-UTR induced by energy metabolism stress. It was shown that, in primary neuronal cultures, glucose deprivation causes BACE1 protein level increase by translational mechanism (Western blotting assay showed a boost of BACE1 protein concentration, and BACE1 mRNA concentration, estimated by RT-qPCR, was not increased). The eIF $2 \alpha$ phosphorylation level was also increased in these cultures. Conforming to this, in in vivo experiments, chronic energy deficit, induced by treatment with energy metabolism inhibitors, caused an increase in eIF2 $\alpha$ phosphorylation, BACE1 level and amyloidogenesis in Tg2576 mice (these mice overexpress human amyloid precursor protein).

To specify which of the eIF2 $\alpha$ kinases is involved with BACE1 level regulation, the authors transiently transfected BACE1-293 cells (HEK-293 stably overexpressing BACE1) with constructs 
encoding dominant-negative PERK (PERKDN) or GCN2 (GCN2DN), and on the next day treated the cells for $12 \mathrm{~h}$ in media with or without glucose. It was shown that glucose-deprivation-induced increases in BACE1 levels were completely prevented by overexpression of PERKDN, but not GCN2DN allele, demonstrating that PERK was the kinase responsible for eIF $2 \alpha$ phosphorylation and the BACE1 increase, and that GCN2 kinase was not involved in this mechanism. To further confirm the role of PERK, a few experiments, in which eIF $2 \alpha$ phosphorylation by PERK was prevented, were performed: cell cultures were transfected with either constitutively active p-eIF $2 \alpha$ phosphatase PP1c regulatory subunit, or with dominant-negative PERK, or with PERK inhibitor P58IPK. In all three cases, in transfected cells, energy deprivation-induced BACE1 increase was blocked, confirming once again that activation of PERK is necessary for the energy-deprivation-induced BACE1 increase. The authors did not address PKR or HRI kinases, because according to literary data, these two kinases are not activated during nutritional deficits [30]. However, in another work, it was demonstrated that HRI kinase is also important in BACE1 translation regulation. Mouse synaptosomes were activated with glutamate, which caused a significant increase in BACE1 and phosphorylated eIF2 $\alpha$ concentrations, as was shown by Western blotting. It was demonstrated before that NO synthesis is a part of the signaling cascade triggered by NMDA receptor activation, so the authors addressed possible NO participation in glutamate-induced BACE1 synthesis boost. Co-treatment with glutamate and 7-NI (NO-synthase inhibitor) did not cause the increase in BACE1 concentration, suggesting that glutamate-induced eIF2 $\alpha$ phosphorylation and BACE1 translation are NO-dependent. This was further confirmed by treating synaptosomes with NO donor SNP, after which BACE1 concentration increased. The same results were obtained with primary cultures of cortical neurons. Next, the authors demonstrated that HRI mRNA and protein are present in human hippocampus, mouse hippocampal neurons and human neuroblastoma cells. Using immunostaining, they also found that HRI is colocalized with the postsynaptic marker PSD95 in the synaptic spines as well as p-eIF2 $\alpha$. To study the role of HRI in BACE1 expression in human neuroblastoma SH-SY5Y cells, two methods were used: a specific HRI inhibitor administration and a transfection with small interfering RNA causing knockdown of HRI expression. Cells pre-incubated with the HRI inhibitor failed to respond to SNP treatment and did not overexpress BACE1 nor increase the levels of phosphorylated eIF2 $\alpha$. Similarly, when HRI expression was knocked down by a specific siRNA, SNP did not up-regulate BACE1 protein. Consistent with these in vitro findings, NOS inhibitor or HRI inhibitor, being administered chronically to mice for one week, induced a significant reduction in the levels of BACE1 and p-eIF2 $\alpha$ in the synaptosomes isolated from the hippocampi of these mice. The authors also demonstrated that the administration of SNP to cells induced spine growth, that was prevented by pre-incubating the cells with the HRI inhibitor, but not with the PKR inhibitor. In experiments in vivo, two paradigms involving hippocampal processing were used: the object-recognition test and the context-recognition test. Inhibitors of HRI or NOS were administered intraperitoneally to mice during the memory consolidation period. Mice that received each of these inhibitors showed a memory impairment in the object-recognition without affecting their exploratory behavior. Similarly, context-recognition memory was significantly compromised by both inhibitors. These data confirm that HRI is essential for BACE1 expression regulation and memory consolidation in mice [14].

\subsection{Glutamate Ionotropic Receptor NMDA Type Subunit 2B (GluN2B)}

Glutamate receptors play a key role in nervous system function, particularly in memory and learning. One of these receptors, $N$-Methyl-D-aspartate receptor (NMDAR), is crucial for synaptic plasticity and participates in both long-term potentiation (LTP) and long-term depression (LTD) [53,54], but its role in LTP is more well-known. This receptor is a heterotetrameric cation channel. While it always consists of four subunits, there are several possible types of these subunits, and combinations of them are different in different NMDAR receptors. Subunit GluN2B is considered to be important for brain development and also for mature neuronal function. GluN2B interacts directly with PSD-95 scaffold protein, and this interaction is the first step in a few intracellular signal cascades 
caused by NMDAR activation. As was shown in experiments with primary neuronal cultures, glutamatergic stimulation causes de-repression of GluN2B translation, providing rapid protein accumulation necessary for neuronal activity, spine growth and memory formation. It was shown that the observed translation shift is regulated by eIF $2 \alpha$ kinase HRI, as the effect was avoided when a specific HRI inhibitor or a small interfering RNA that binds with HRI mRNA (siHRI) were used. GluN2B translational de-repression was also dependent on $\mathrm{Ca}^{2+}$ signaling and mediated by neuronal NO-synthase, since treatment with either $\mathrm{Ca}^{2+}$ chelator or nNOS inhibitor prevented the glutamate-induced increase in GluN2B expression. Similar results were obtained in cortical synaptosomes and in isolated postsynaptic membranes. The authors proposed that HRI is activated following the interaction of NO with its heme sensor, inducing a transient phosphorylation of eIF2 $\alpha$. GluN2B mRNA has a long $5^{\prime}$-UTR with three uORFs. Human neuroblastoma cells, transfected with the wild type GluN2B 5'-UTR-containing construct, showed reduced luciferase reporter expression compared to control cells (transfected with the vector without this $5^{\prime}$-UTR). Treatment with NO donor SNP caused a significant increase in reporter expression in these cells. Mutation of all three upstream AUGs reversed 5'-UTR-dependent basal translation repression, but in this case SNP did not cause changes in reporter expression level, so GluN2B mRNA lacking these three uORFs is unable to shift its translation rate after glutamate receptor activation [15].

\subsection{Oligophrenin-1}

The paper by Di Prisco et al. [28] is also dedicated to glutamate signaling. These authors focused on another type of glutamate receptors: group I mGluRs. These receptors are metabotropic and bear no structural resemblance to NMDAR, but like NMDAR, mGluRs are also very important for synaptic plasticity and may facilitate both LTP and LTD [55]. However, currently there is more data about mGluR-dependent LTD. Unlike NMDAR-dependent LTD, which persists after treatment with translation inhibitors, the mGluR-LTD mechanism requires rapid protein synthesis within minutes after receptor activation [56]. The shift in translation during mGluR-LTD resembles some processes typical for LTP: for mGluR-LTD, eIF2 $\alpha$ phosphorylation is also crucial, and there is a decrease in overall translation paired with the intensification of translation of specific mRNAs. One of the main results of mGluR-LTD that is observed at the cell proteome level is a diminishing of surface AMPA-receptors density at synapses. Di Prisco et al. identified eIF2 as a master effector of mGluR-LTD-dependent translation changes using a few different experimental approaches.

First, they activated mGluR in mouse hippocampal slices with dihydroxyphenylglycine (DHPG, a selective mGluR1/5 agonist) and demonstrated that DHPG causes mGluR-LTD and consistently increases eIF $2 \alpha$ phosphorylation in the slices. Sal003, a selective inhibitor that blocks p-eIF2 $\alpha$ phosphatases, had the same effects, but Sal003-induced LTD was also insensitive to mGluR1 and mGluR5 antagonists, indicating that the increase in eIF2 $\alpha$ phosphorylation may be a downstream effect of mGluR activation.

To test whether eIF $2 \alpha$ phosphorylation is required for mGluR-LTD at CA1 synapses, the authors used Eif $2 s 1^{S / A}$ heterozygous knock-in mice, containing one mutant eIF2 $\alpha$-encoding allele (in mutant protein, the phosphorylation site is absent). These mice have reduced background eIF2 $\alpha$ phosphorylation in the hippocampus. In experiments with acute hippocampal slices, DHPG or paired-pulse low frequency stimulation caused mGluR-LTD in wild-type, but not Eif2s1 $1 / A$ slices. Still, NMDAR-LTD, elicited by low frequency stimulation, occurred normally in Eif2s1 $1^{S / A}$ slices, indicating that eIF $2 \alpha$ phosphorylation is necessary only for the protein synthesis-dependent variant of LTD. Another transgenic mouse line (fPKR) was used to investigate the effect of opposite change-overly increased eIF $2 \alpha$ phosphorylation-on LTD formation in CA1 neurons. Using the Cre-loxP recombination technique, the authors modified the PKR gene in some neurons to make PKR catalytic activity inducible by a specific chemical agent, and simultaneously tagged these neurons with green fluorescent protein (GFP). In paired recordings from GFP - and GFP+ neurons, the PKR activity-inducing agent generated a sustained LTD only in GFP+ neurons, so the upregulation of PKR 
activity alone is enough for LTD induction. Taken together, these data indicate that PKR kinase is necessary for mGluR-LTD-caused eIF2 $\alpha$ phosphorylation. Supposedly, GCN2 may be also important for this process: these two kinases are synergic in suppression of long-term potentiation, as was demonstrated previously in experiments with hippocampal slices [12,26,57].

To further explore translation changes paired with mGluR-LTD, RNA-seq was used to analyze total mRNA abundance, mRNAs that are poorly or not translated (monosome fraction), and the actively translating mRNAs (polysome fraction) in control and DHPG-treated cultured mouse neurons. The authors identified mRNAs for which translation was induced by DHPG and checked if there are uORFs in their $5^{\prime}$-UTRs. Altogether, 324 different mRNAs for which translation was upregulated by mGluR activation were discovered, 72 of them containing uORFs. This list included subunits of membrane receptors, ion channels, translation factors, kinases and other enzymes participating in intracellular signaling pathways (the full list is available in supplementary data to the discussed article). However, upregulation of oligophrenin-1 (Ophn1) mRNA translation caused by mGluR-LTD became the most important result of this screening. Oligophrenin-1 is a Rho-GTPase-activating protein which is necessary for intracellular signal transduction and regulation of actin cytoskeleton restructuring. It is important for proper spine formation, activity-dependent maturation and plasticity of excitatory synapses, maintaining their structural and functional stability. Mutation of oligophrenin-1 has been associated with X-linked mental retardation, a hereditary condition with some characteristic abnormalities in brain morphology [58]. Oligophrenin-1 mRNA harbors two uORFs in its 5'-UTR. To test whether these uORFs are cis-acting regulators of the translation rate, a genetic construct, in which the $5^{\prime}$-UTR of Ophn1 was fused to the coding region of the luciferase reporter, was transfected to HEK-293T cells. The expression of this construct was reduced compared to the control vector without Ophn1 mRNA 5'-UTR. In cells treated with thapsigargin (a toxin that causes cellular stress and eIF2 $\alpha$ phosphorylation), translation of the Ophn1 mRNA $5^{\prime}$-UTR-containing construct was upregulated, which confirms that uORFs are necessary for switching the translation level of Ophn1 [28].

It was demonstrated before that hippocampal LTD is crucial for object-place recognition, so to test LTD-dependent changes in vivo, Di Prisco et al. chose the spatial recognition task, in which the same objects are presented twice in two days. ISRIB (an agent that prevents the translational effects of eIF2 $\alpha$ phosphorylation) administered to mice before training caused an increase in object exploration time at the reexposure day (notably, ISRIB had no effect on distances traveled or exploration times during training). Conforming to that, mutant $E i f 2 s 1^{S / A}$ mice also spent more time exploring the objects during reexposure compared to the wild-type mice. Both these findings show that eIF2-mediated translational control is needed to successfully learn the novel object-space configuration. Also, Ophn1 shRNA-injected mice spent significantly more time exploring the objects during reexposure compared to control mice (injected with scrambled shRNA). So, behavioral experiments also confirmed the importance of oligophrenin-1 for LTD formation and correlation between oligophrenin-1 function and eIF $2 \alpha$ phosphorylation [28]. At the same time, in the abovementioned study by Biever et al. with amphetamine-treated animals, Ophn1 mRNA was not enriched in polysomal fractions, and the oligophrenin-1 protein level in lysates remained unchanged, suggesting that oligophrenin-1 is not important for catecholamine-induced neuronal activation [32].

2.6. Postsynaptic Density Proteins: Synapse-Associated Protein 90/Postsynaptic Density Protein-95-Associated Protein 3 (SAPAP3) and SH3 and Multiple Ankyrin Repeat Domains 1 (Shank1)

In postsynaptic density, SAPAP3, Shanks and PSD-95 are the three master scaffolding proteins that cross-link neurotransmitter receptors, signaling molecules and cytoskeletal components [34].

SAPAP3 stands for synapse-associated protein 90/postsynaptic density protein-95-associated protein 3 (also known as DLGAP3, DLG associated protein 3). Mutations of SAPAP3 were shown to be important for pathogenesis of obsessive-compulsive disorder [59,60]. SAPAP3 mRNA is long, GC-rich and contains four uORFs, but only uORF2 overlaps with the main frame: in the sequence AUGA, the last two nucleotides of the SAPAP3 start codon AUG are simultaneously the first two 
nucleotides of the uORF2 stop codon UGA. Using molecular constructs with AUG substituted to AAG in different uORFs, it was confirmed that only the second uORF strongly down-regulates translation efficiency. Ribosomes translating uORF2 bypass $\mathrm{AUG}^{+1}$ and are thus unable to synthesize full-length SAPAP3 [34]. Moreover, the alternative translation initiation site within the same protein-coding frame $\left(\mathrm{AUG}^{+277}\right)$ is present in SAPAP3 mRNA, and so two distinct SAPAP3 protein isoforms may be produced. It was shown that concentrations of these two isoforms vary in different rodent brain regions: SAPAP3 $\beta$ (truncated isoform) is the predominant isoform in the hippocampus, thalamus, cerebellum and brain stem, while in olfactory bulb, SAPAP3 $\alpha$ (the long isoform) prevails, and in the neocortex, both isoforms are presented equally. In an experiment with transfected HEK293 cells, point mutation of UORF2 in SAPAP3 mRNA shifted the isoforms' ratio in favor of SAPAP3 $\alpha$, so $\mathrm{UORF} 2$ is not only necessary for mRNA translation inhibition, but also may be important for isoforms' proportion regulation. It may be speculated that ribosomes translating uORF2 bypass $\mathrm{AUG}^{+1}$, stop translation shortly thereafter and may subsequently reinitiate translation at $\mathrm{AUG}^{+277}$ leading to SAPAP3 $\beta$ synthesis (noteworthy, the first $300 \mathrm{nt}$ of the SAPAP3 ORF are highly conserved in various vertebrate species). To assess whether eIF2 $\alpha$ phosphorylation may affect the relative initiation rates occurring at $\mathrm{AUG}^{+1}$ and $\mathrm{AUG}^{+277}$ of SAPAP3 mRNA in vivo, SAPAP $3 \alpha \mathrm{SAPAP} 3 \beta$ ratios were calculated in the neocortex, hippocampus and cerebellum of heterozygous eIF $2 \alpha^{+/ S 51 A}$ knock-in mice possessing reduced p-eIF $2 \alpha$ levels. Unexpectedly, isoform ratios were found to be unaltered in mutant mice compared to wild-type mice, suggesting that while uORF2 is a cis-regulating element of SAPAP3 mRNA, eIF2 may not be important for its control and it is regulated by some alternative ways. In this work, no experiments with eIF2 $\alpha$ kinases were performed [34].

Shank1 (SH3 and multiple ankyrin repeat domains 1) also has complicated translational regulation. Shank family proteins regulate the morphology of dendritic spines, and Shank1 mRNA is abundant in dendrites of hippocampal neurons and cerebellar Purkinje cells. In humans, mutations in genes coding Shank proteins have been associated with mental retardation and autism. It was shown that translation of human Shank1 mRNA is inhibited by its own $5^{\prime}$-UTR. The organization of this $5^{\prime}$-UTR is very complex. To begin with, it has high GC content and forms an intricate secondary structure. Also, this $5^{\prime}$-UTR contains two alternative translation initiation sites within the same protein-coding frame ( $\mathrm{AUG}^{+1}$ and $\mathrm{AUG}^{+214}$, producing two protein isoforms), three "normal" uORFs starting with AUG (from which uORF3 is the most important because it overlaps with $\mathrm{AUG}^{+1}$ ), and, most unusually, another uORF starting with the non-canonical ACG start codon (and overlapping with uORF3). To analyze the role of each uORF for translation efficiency, uORFs were individually disabled by point mutations within the context of luciferase reporter vectors, and the translation rate of fused mRNAs was assayed in a cell-free system (rabbit reticulocyte lysate), in HEK cells or in cortical neurons. Mutations of uORFs 1 or 2 did not alter the reporter translation rate, and mutation of uORF3 increased it, as was expected. However, mutation of the ACG start site caused almost complete loss of translation initiation at $\mathrm{AUG}^{+1}$, that was partially restored by additional uORF3 mutation. So, it was demonstrated that the extraordinary ACG uORF does not inhibit main frame translation but, on the contrary, maintains it, presumably by competing with inhibiting uORF3 for ribosomes and translation factors. Ribosomes that started translation at ACG uORF would bypass uORF3 and are therefore capable of reinitiating translation at $\mathrm{AUG}^{+1}$ to synthesize the full-length isoform of Shank1. Further evidence of the exceptional properties of Shank1 mRNA $5^{\prime}$-UTR is that cellular stress did not change the translation rate of reporter mRNAs fused to this $5^{\prime}$-UTR, indicating that eIF $2 \alpha$ phosphorylation does not influence Shank1 translation. So, despite some similarities with p-eIF $2 \alpha$-dependent mRNAs, Shank1 mRNA is regulated by its own unique mechanisms [35].

\subsection{Neuron-Specific BCL2-Antagonist/Killer (N-Bak), a Constitutively Repressed Pro-Apoptotic Protein}

Bak (BCL2-antagonist/killer) is a pro-apoptotic factor. When activated, Bak and related protein Bax generate pores in the mitochondrial membrane, causing mitochondrial proteins to be released into cytosol to advance apoptosis. Unlike other types of cells, neurons do not express a classical 
form of Bak mRNA, because in neurons premature Bak mRNA is entirely spliced. The protein that may be translated from this spliced mRNA is called N-Bak. This protein is able to be translated and can be detected by specific antibodies, as was demonstrated in experiments with an in vitro translation system or transiently transfected HeLa cells [61]. Artifical overexpression of N-Bak induced apoptosis in cortical, hippocampal and cerebellar neurons but had an unexpected anti-apoptotic effect in sympathetic neurons [62].

N-Bak mRNA is present and stable in the brain and in cultured primary neurons and stored in granular structures, as was shown by in situ hybridization [36]. Despite the presence of its mRNA, $\mathrm{N}$-Bak protein is not detectable in the same neurons. Presumably, an earlier report in which N-Bak was revealed in neurons by Western blotting [62] was erroneous, since in later studies it was established that the band that is occasionally recognized by anti-Bak antibodies and has expected molecular weight is actually non-specific [36]. Experiments with proteasome inhibitors demonstrated that the absence of $\mathrm{N}$-Bak protein is not caused by its rapid proteasome-mediated degradation [61]. Instead, the N-Bak mRNA appears to be under a strong translational block.

$5^{\prime}$-UTR is the same in both Bak and N-Bak transcripts. This $5^{\prime}$-UTR is not well conserved, and may contain one or two uORFs in different species. Jakobson et al. worked with mouse neurons and chose to address the first of two mouse uORFs, because it is in the context of the Kozak consensus sequence. Genetic constructs containing luciferase reporter downstream of wild-type or mutated N-Bak $5^{\prime}$-UTR (in mutated form, 38 nucleotides encompassing AUG of the first uORF were deleted) were made and transfected to mouse neuroblastoma Neuro-2a cells. The deletion increased luciferase activity, suggesting that $\mathrm{uORF} 1$ is important for translation repression. However, in this case, $\mathrm{uORF}$ is not the only mechanism of translation arrest: $3^{\prime}$-UTR of N-Bak mRNA also contributes to this, since it contains premature termination codon and exon-exon junction that are known to be necessary for nonsense-mediated translation repression (see [63] for the exact mechanism of this). In experiments with constructs containing wild-type or mutated $3^{\prime}$-UTR, the authors confirmed that these $3^{\prime}$-elements indeed diminish the reporter translation.

Jakobson et al. supposed that, like many mRNAs with uORFs, N-Bak mRNA translation may be "turned on" during cell stress by eIF $2 \alpha$ phosphorylation; considering that N-Bak must be an apoptotic factor, they also performed an experiment with induction of apoptosis. Cellular stress was induced by thapsigargin; it was shown that the used dose of thapsigargin induced the maximal level of eIF2 $\alpha$ phosphorylation. To induce mitochondrial apoptosis, cultured superior cervical ganglion neurons were deprived of nerve growth factor, and cortical neurons were treated with etoposide (an inhibitor of topoisomerase II) in the presence of caspase inhibitors. However, unexpectedly, endogenous N-Bak mRNA was still not translated in neurons during cellular stress, or even in apoptotic neurons, as was shown by antibodies and additionally confirmed with quantitative mass spectrometry analysis. Moreover, the dense N-Bak-mRNA-containing granules were still clearly visible in stressed or apoptotic neurons. It means that this protein does not participate in the classical apoptosis or stress response in neurons. Whether the N-Bak mRNA is ever released from the translational block is still unclear [36], but it may be speculated that N-Bak translation is perhaps permitted only in particular cases of apoptosis induced by some specific factors.

\subsection{Protein Kinase $M \zeta$, "the Memory Molecule"}

One of the important neuronal proteins regulated by uORFs is an enzyme necessary for synaptic plasticity: atypical protein kinase $\mathrm{M} \zeta(\mathrm{PKM} \zeta)$. We are particularly interested in this kinase, so we decided to describe its regulation and functions more minutely and devote the whole next section to it. 


\section{Protein Kinase $\mathbf{M} \zeta$, Its Functions and Regulation of Its Translation}

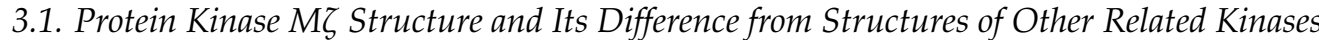

In the group of PKC Ser/Thr protein kinases, there are three subfamilies: conventional, novel and atypical PKCs (aPKCs). aPKC isoenzymes $\mathrm{PKC} \zeta$ and $\mathrm{PKCl} / \lambda$ have a functional role in insulin signaling, and their dysfunction correlates with insulin-resistance disorders. aPKCs, in contrast to other PKC subfamilies, are not regulated by diacylglycerol and $\mathrm{Ca}^{2+}$, because aPKCs lack the calcium-sensitive C2 domain and have a dysfunctional DAG-sensitive C1 domain [64,65]. Despite their participation in insulin-controlled pathways, aPKCs are also insulin-unresponsive [66]. These atypical kinases have a protein binding PB1 domain at their regulatory N-terminus and a PDZ ligand at the C-terminus [64]. Most PKCs, including aPKCs, also have an autoinhibitory pseudosubstrate segment. This pseudosubstrate blocks the active center of the enzyme, and for kinase activation the pseudosubstrate has to be relocated via binding to protein scaffolds, such as PAR6 [67] and p62 [68]. aPKC isoenzymes must be constitutively phosphorylated for their work. Their phosphorylation is independently regulated by two kinases: ribosome-associated mammalian target of rapamycin complex 2 (mTORC2) mediates co-translational phosphorylation of the turn motif, followed by phosphorylation at the activation loop by phosphoinositide-dependent kinase-1 (PDK1). PKC $\zeta$ has a very low turn-over (about five reactions per minute). It was proposed that scaffolding near substrates may be rate-limiting for PKC $\zeta$ function [66].

The PKC $\zeta$ kinase has a shorter alternate transcript, $\mathrm{PKM} \zeta$, that is expressed exclusively in the central nervous system [69]. This truncated kinase contains only the C-terminal catalytic domain and lacks all N-terminal regulatory domains (PB1, pseudosubstrate and atypical C1) (Figure 2), so it is constitutively active, and because of this its concentration in the cell should be extremely well controlled.

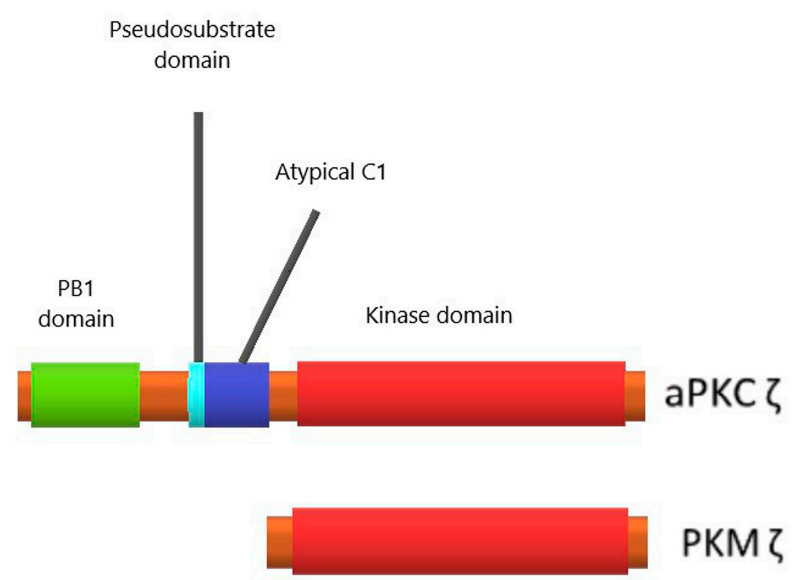

Figure 2. Domain structure of protein kinase $\mathrm{C} \zeta(\mathrm{PKC} \zeta)$ and its truncated alternative transcript, protein kinase $\mathrm{M} \zeta(\mathrm{PKM} \zeta)$. In $\mathrm{PKC} \zeta, \mathrm{PB} 1$ is the protein-binding domain, pseudosubstrate is a cis-inhibitory element, atypical C1 interacts with diacylglycerol, but it lacks determinants that allow the binding. $\mathrm{PKM} \zeta$ is devoid of all regulatory elements and contains only catalytic domain.

\subsection{Protein Kinase $M \zeta$ Cellular Localization and Function}

Newly synthesized $\mathrm{PKM} \zeta \mathrm{mRNA}$ is transported to dendrites by the dendrite-targeting element in its untranslated region [70]. Somatodendritic localization of $\mathrm{PKM} \zeta$ in cortical and hippocampal neurons was shown by light and electron microscopy. Immunogold staining revealed PKM $\zeta$ distribution in spines near or associated with the postsynaptic density, but not in the presynaptic terminal. Also, in some neurons, nuclear localization of PKM $\zeta$ was reported [71].

Many researchers suggest that $\mathrm{PKM} \zeta$ is a molecule crucial for memory maintenance [72-78]. 
This idea is based on the following data:

1. Long-term potentiation and memory are accompanied by increasing of the PKM $\zeta$ protein level in memory-associated structures [79-82];

2. $\mathrm{PKM} \zeta$ inhibitor ZIP erases established memory in mammals and invertebrates $[73-75,82,83]$;

3. $\mathrm{PKM} \zeta$ inhibitor ZIP disrupts the late phase of long-term potentiation, a cellular model of synaptic plasticity and memory $[72,81,84]$;

4. Knockdown of $\mathrm{PKM} \zeta$ in the hippocampus impairs long-term potentiation and negatively regulates memory maintenance $[85,86]$;

5. Overexpression of PKM $\zeta$ enhances memory [87-89].

$\mathrm{PKM} \zeta$ participates in synaptic plasticity control in many ways, as among its substrates are transcription and translation regulators and proteins participating in the rearrangement of postsynaptic density.

Neuronal stimulation induces $\mathrm{PKM} \zeta$ translocation to the nucleus, where it can affect transcription by direct phosphorylation of CBP (CREB-binding protein), that subsequently increases the acetylation level of histones H2B and $\mathrm{H} 3$ [90].

Translation regulation by PKM $\zeta$ may be realized via initiation factors eIF4B and eIF4E. PKM $\zeta$ directly phosphorylates eIF4B [2]. Phosphorylation of this factor leads to a strong increase in its affinity for non-coding BC1/BC200 RNA. This brain-specific RNA competes with 18S rRNA for translation initiation factors, thereby ensuring a low level of protein synthesis in the neuron [91]. Therefore, phosphorylation of eIF4B by PKM $\zeta$ suppresses overall translation in neurons. Also, PKM $\zeta$ phosphorylates Pin1, a peptidyl-prolyl isomerase that may change conformations of initiation factor eIF4E and its regulating proteins and thus suppress translation. Phosphorylation by $\mathrm{PKM} \zeta$ decreases Pin1 binding to translation regulators, promoting protein synthesis [92]. Taken together, these facts let us conclude that PKM $\zeta$ may be involved in both translation suppression and translation activation mechanisms.

Also, $\mathrm{PKM} \zeta$ participates in the regulation of the function of AMPA glutamate receptors. These receptors are inserted in the postsynaptic membrane during LTP processes, and, on the contrary, removed from the membrane during LTD. PICK1 (protein interacting with C-kinase 1) retains AMPA receptors under the membrane by interaction with the GluA2 subunit of the receptor, preventing its insertion into the postsynaptic membrane. PKM $\zeta$ disrupts PICK1-GluA2 interaction, after which the GluA2-containing AMPA receptor may be inserted into the membrane [93]. Besides, it was shown that PKM/PKC $\zeta$ blocker ZIP prevents chemically induced GluA1 and GluA2 phosphorylation, which may indirectly confirm the physiological role of PKM $\zeta$ in AMPA receptor phosphorylation [94,95]. Moreover, cocaine induces a GluA1 level increase in nucleus accumbens after conditioned place preference training, and this effect was prevented by PKM $\zeta$ inhibitor ZIP [96]. We can suggest that GluA1 increase can be explained by PKM $\zeta$-dependent control of translation.

In addition, it was shown that $\mathrm{PKM} \zeta$ regulates phosphorylation of the palmitoylation enzyme zinc finger DHHC-type containing 8 (ZDHHC8), which palmitoylates PSD-95, the major scaffold protein at excitatory synapses. By this, ZDHHC8 promotes PSD-95 insertion to synapse. Inhibition of $\mathrm{PKM} \zeta$ leads to a decrease of synaptic PSD-95 accumulation in vivo, which can be rescued by the overexpression of ZDHHC8 [97].

There are other putative substrates of PKM $\zeta$ that have yet to be confirmed experimentally. Based on the similarity of PKM $\zeta$ and PKC $\zeta$ kinase domains, we speculate that these kinases can phosphorylate the same targets. It was shown that PKC $\zeta$ activates mTOR signaling, which regulates protein translation and proliferation, in pancreatic $\beta$ cells and follicular lymphoma [98,99]. It is possible that $\mathrm{PKM} \zeta$ can also regulate $\mathrm{mTOR}$ activation in neurons. 


\subsection{Protein Kinase M Translation Regulation: The Role of eIF $2 \alpha$ Phosphorylation and Other Possible Mechanisms}

$\mathrm{PKM} \zeta$ protein translation in neurons is strongly (but not completely) inhibited. It was demonstrated that $\mathrm{PKM} \zeta$ synthesis depends on many signaling pathways that are involved in LTP (PI3-kinase, CaMKII, MAPK, PKA, mTOR cascades) [81]. Neuronal stimulation causes an increase in the translation of $\mathrm{PKM} \zeta$ in postsynapses, and this increase is necessary for successful LTP formation [76]. The mRNA encoding PKM $\zeta$ has an extended $5^{\prime}$-UTR. During the splicing process, the $5^{\prime}$-UTR of PKM $\zeta$ mRNA is modified, and its sequence is unique [69]. Within this $5^{\prime}$-UTR, there are seven short uORFs, which is unusually many. In the work performed in our lab [37], we demonstrated that these $\mathrm{uORF}$ s play a critical role in the regulation of PKM $\zeta$ translation. Elimination of these uORFs by point mutations (AUG to UAG) activated translation of the reporter fluorescent protein in a cell-free system and in primary cultures of rat hippocampal neurons. It seems that all or at least most of seven uORFs contribute to the repression of the main frame translation, because in the succession of genetic constructs, containing 7, 6, 5, 4 or 0 active uORFs in their $5^{\prime}$-UTR, the reporter translation rate increased gradually. We also demonstrated that in cell-free translation systems, translational initiation complexes are formed only on uORFs. Further, we observed an increase in the translation of the reporter protein under the control of wild-type PKM $\zeta 5^{\prime}$-UTR in neuronal culture during non-specific activation by picrotoxin; in cells transfected with a construct containing mutated PKM $\zeta 5^{\prime}$-UTR without uORFs, there was no such PKM $\zeta$ translation inducibility. Finally, we showed that such a mechanism is similar to the mechanism involved in cell stress response, as application of sodium arsenite to neuron cultures induced translation of mRNA carrying PKM $\zeta 5^{\prime}$-UTR similarly to picrotoxin activation (and again, in cells transfected by a construct without uORFs, arsenite treatment did not change the reporter translation rate). Such similarity of translation shift in neuronal activation and stress response is an indirect indication that phosphorylation of eIF $2 \alpha$ may be the main regulator of PKM $\zeta$ translation. There are literary data supposing that the eIF $2 \alpha$ kinase responsible for this regulation may be PERK: in the hippocampal area CA1 of APP/PS1 mice (an animal model of Alzheimer's disease), PKM concentration is reduced, and conditional deletion of PERK restored PKM $\zeta$ expression back to the normal level [31]. These data may indicate that PERK, unexpectedly, participates in downregulation of PKM $\zeta$, but this conclusion would be based on indirect evidence. To determine if PERK actually regulates PKM $\zeta$ expression, additional experiments with overexpression of PERK in wild-type animals are necessary.

We also demonstrated that for the effective synthesis of $5^{\prime}$-UTR PKM $\zeta$, initiation factors eIF4A and eIF4B did not significantly facilitate translation on PKM $\zeta 5^{\prime}$-UTR. However, the truncated form of eIF4G enhanced the efficiency of translation of mRNA with PKM $\zeta 5^{\prime}$-UTR [37]. $\triangle$ eIF4G is able to interact with the $40 \mathrm{~S}$ ribosomal subunit and to bind with mRNA via eIF3, but cannot be involved in the cap-dependent initiation of translation. This form of eIF4G increases the probability of re-initiation events in cell-free systems on uORFs [100]. Activation of translation on the PKM $\zeta 5^{\prime}$-UTR by $\triangle$ eIF4G confirms the suggestion on the crucial role of $\mathrm{uORFs}$ in translational control of the PKM $\zeta$ synthesis [37].

$\mathrm{PKM} \zeta$ translation may be additionally regulated via Pin1, since in brain lysates of Pin1 $1^{-/-}$ mice, both $\mathrm{PKC} \zeta$ and $\mathrm{PKM} \zeta$ concentration were increased, but the exact molecular mechanism of this regulation has not yet been investigated. Considering that, as was mentioned above, PKM $\zeta$ inhibits Pin1 activity, a feedback with mutual inhibition may be proposed for these two proteins [92].

All PKM $\zeta$ interactions with its substrates and regulators are presented schematically in Figure 3. 


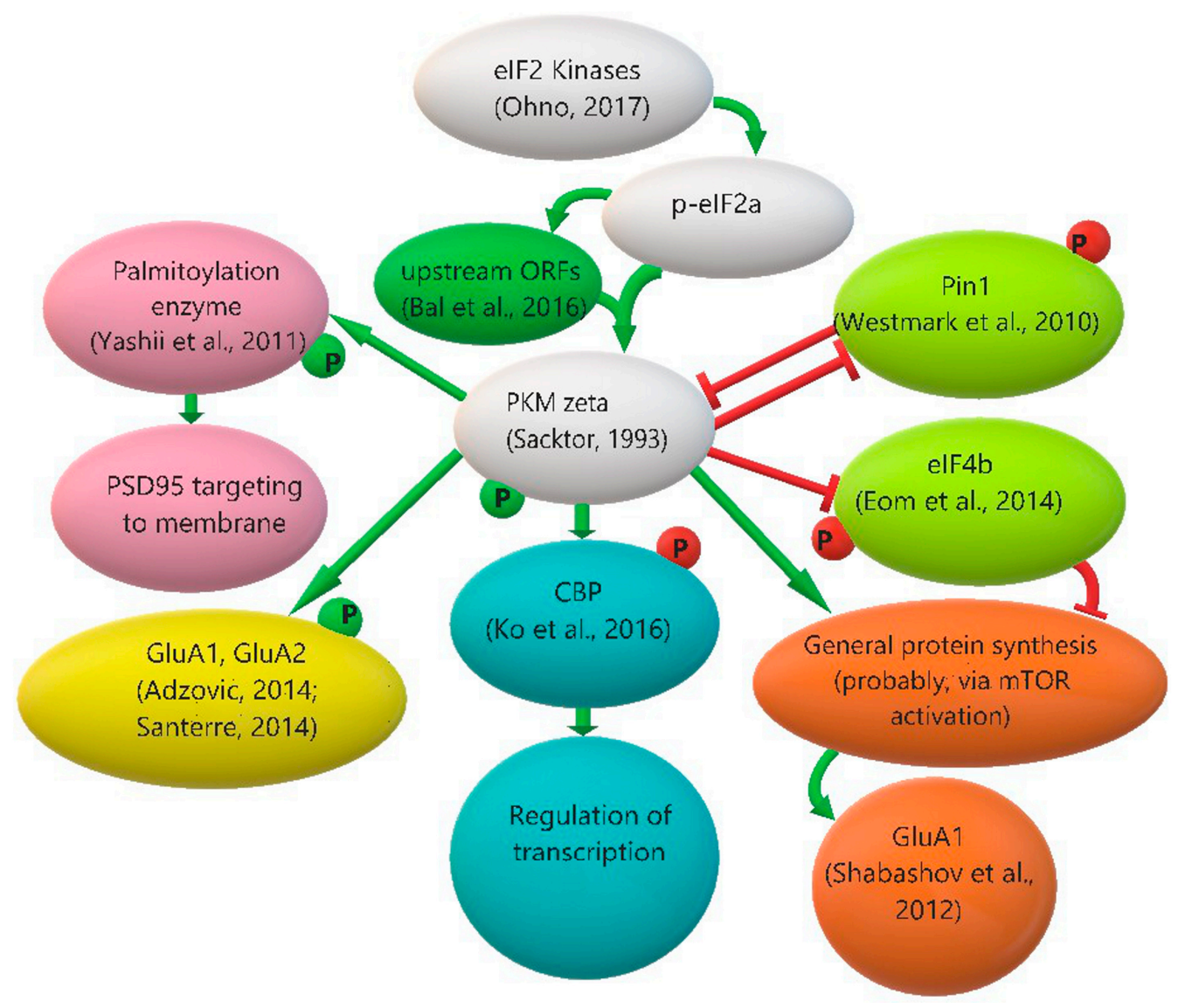

Figure 3. A diagram of $\mathrm{PKM} \zeta$ kinase regulation and functions. eIF2 - eucaryotic translation initiation factor 2; p-eIF2a - phosphorylated $\alpha$-subunit of eucaryotic translation initiation factor 2; P - phosphate group; ORF - open reading frame; PKM zeta - protein kinase $M \zeta$; Pin1 - peptidyl-prolyl cis-trans isomerase NIMA-interacting 1; PSD95 - postsynaptic density protein 95; eIF4b - eucaryotic initiation factor 4B; CBP - CREB-binding protein; GluA1, GluA2 - glutamate ionotropic receptor AMPA type subunits 1 and 2; mTOR - mammalian target of rapamycin. A detailed explanation of this scheme is presented in Sections 3.2 and 3.3.

\section{Summary}

Phosphorylation of eIF2 $\alpha$-subunit in neurons leads to a translation shift, suppressing overall translation by a dramatic reduction of the cap-dependent initiation rate while simultaneously increasing the translation of specific mRNAs for which initiation is suppressed in other conditions due to the structure of their $5^{\prime}$-UTRs. It was shown that all four kinases of eIF $2 \alpha$ may participate in neuron-specific regulation of these mRNAs; moreover, in many cases, different eIF $2 \alpha$ kinases may supposedly be synergic or even interchangeable in their function in neuronal plasticity. p-eIF $2 \alpha$-dependent translation regulation allows the neuron to quickly change protein ensembles at the synapse in an activity-dependent manner, and such regulation is important for both LTP and LTD formation. So, further understanding of eIF2 function in neurons should be an important topic in studying synaptic plasticity. Another essential matter is a potential therapeutic application of researches considering eIF $2 \alpha$ phosphorylation. There is a constantly increasing amount of recent data suggesting that eIF2 pathway dysregulation may be an important factor of pathogenesis of many disorders-first of all, Alzheimer's disease [6,30,31]. So, eIF2 and kinases of its $\alpha$-subunit, especially PERK and GCN2, may be considered as promising targets for new nootropic medicines. There are also emerging data worth mentioning that p-eIF $2 \alpha$ phosphatases, that we did not thoroughly discuss here, may also serve as valid drug targets [101]. 
Acknowledgments: This review was supported by the Russian Science Foundation (Grant No. 14-25-00072).

Conflicts of Interest: The authors declare no conflict of interest.

\section{Abbreviations}

$\triangle \mathrm{eIF} 4 \mathrm{G}$

$3^{\prime}$-UTR

$5^{\prime}$-UTR

7-NI

AMPA

aPKC

APP

ATF4

ATF5

ATF6

ATP

BACE1

BACE1-293

Bax

BC1/BC200 RNA

BDNF

BiP/GPR78

C1

$\mathrm{C} 2$

CA1

CaMKII

CBP

CHO-K1

CHOP

CREB-2

C-terminal

DAG

DDIT3

DHPG

dsRBM

ds-RNA

eIF2

eIF2 $\alpha$

eIF3

eIF4B

eIF4E

eIF4G

ER

G-actin

GADD34

GCN1

GCN2

GCN2DN

GFP

GluA1

GluA2

GluN2B

GTP

$\mathrm{H} 2 \mathrm{~B}$

H3
Truncated eucaryotic translation initiation factor $4 \mathrm{G}$

$3^{\prime}$-Untranslated region

$5^{\prime}$-Untranslated region

7-Nitroindazole

$\alpha$-Amino-3-hydroxy-5-methyl-4-isoxazolepropionic acid

Atypical protein kinase $C$

Amyloid precursor protein

Activating transcription factor 4

Activating transcription factor 5

Activating transcription factor 6

Adenosine triphosphate

Beta-site APP-cleaving enzyme 1

HEK-293 cells stably overexpressing BACE1

BCL-2-associated X protein

Brain cytoplasmic RNA

Brain-derived neurotropic factor

Binding immunoglobulin protein (BiP), also known as $78 \mathrm{kDa}$ glucose-regulated protein

Protein kinase $\mathrm{C}$ conserved region 1

Protein kinase $\mathrm{C}$ conserved region 2

Cornu Ammonis region 1

$\mathrm{Ca}^{2+} /$ calmodulin-dependent protein kinase II

CREB-binding protein

Chinese hamster ovary K1 cells

CCAAT-enhancer-binding protein homologous protein

cAMP-response element binding protein 2

Carboxyl terminal

Diacylglycerol

DNA damage-inducible transcript 3

Dihydroxyphenylglycine

Double-stranded RNA binding motif

Double-stranded RNA

Eucaryotic translation initiation factor 2

$\alpha$-subunit of eucaryotic translation initiation factor 2

Eucaryotic translation initiation factor 3

Eucaryotic translation initiation factor $4 \mathrm{~B}$

Eucaryotic translation initiation factor $4 \mathrm{E}$

Eucaryotic translation initiation factor $4 \mathrm{G}$

Endoplasmic reticulum

Globular actin

Growth arrest and DNA damage-inducible protein

General control of amino-acid synthesis 1-like protein 1

General control nonderepressible 2 (kinase)

Dominant-negative GCN2 allele

Green fluorescent protein

Glutamate ionotropic receptor AMPA type subunit 1

Glutamate ionotropic receptor AMPA type subunit 2

Glutamate ionotropic receptor NMDA type subunit 2B

Guanosine triphosphate

Histone 2B

Histone 3 


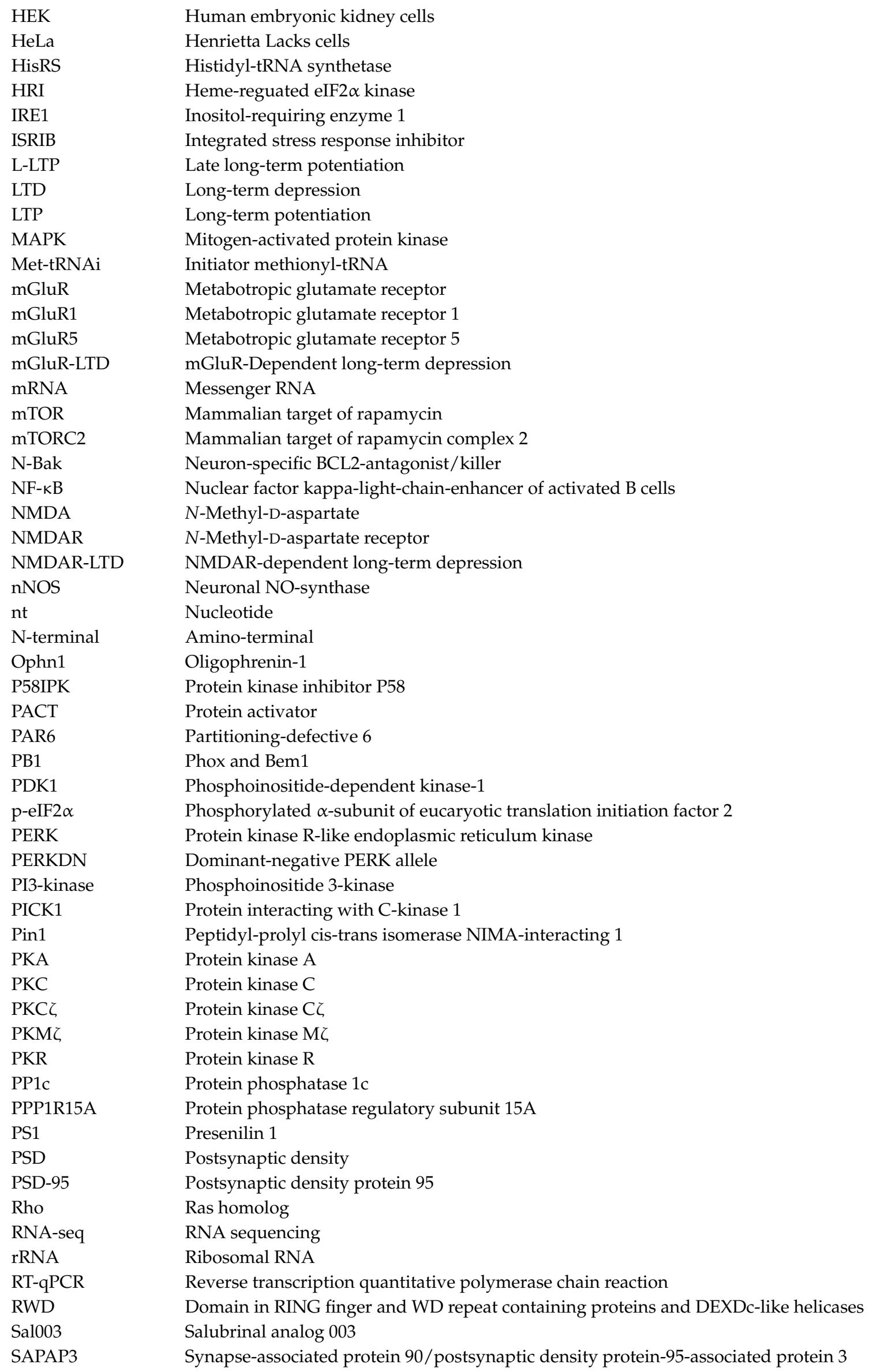




$\begin{array}{ll}\text { Shank1 } & \text { SH3 and multiple ankyrin repeat domains } 1 \\ \text { shRNA } & \text { Small hairpin RNA } \\ \text { siHRI } & \text { Small interfering RNA that binds with HRI mRNA } \\ \text { siRNA } & \text { Small interfering RNA } \\ \text { SNP } & \text { Sodium nitroprusside } \\ \text { SS } & \text { Signal sequence } \\ \text { STAT } & \text { Signal transducer and activator of transcription } \\ \text { Tg2576 } & \text { A } \beta P P-\text { transgenic } 2576 \text { mice } \\ \text { TM } & \text { Transmembrane segment } \\ \text { tRNA } & \text { Transfer RNA } \\ \text { uORF } & \text { Upstream open reading frame } \\ \text { UPR } & \text { Unfolded protein response } \\ \text { UV } & \text { Ultraviolet } \\ \text { VEGF-A } & \text { Vascular endothelial growth factor A } \\ \text { XBP-1 } & \text { X-box binding protein 1 } \\ \text { ZDHHC8 } & \text { Zinc finger DHHC-type containing } 8 \\ \text { ZIP } & \text { Zeta inhibitory peptide }\end{array}$

\section{References}

1. Bramham, C.R.; Wells, D.G. Dendritic mRNA: Transport, translation and function. Nat. Rev. Neurosci. 2007, 8, 776-789. [CrossRef] [PubMed]

2. Eom, T.; Muslimov, I.A.; Tsokas, P.; Berardi, V.; Zhong, J.; Sacktor, T.C.; Tiedge, H. Neuronal BC RNAs cooperate with eIF4B to mediate activity-dependent translational control. J. Cell Biol. 2014, 207, 237-252. [CrossRef] [PubMed]

3. Halliday, M.; Mallucci, G.R. Targeting the unfolded protein response in neurodegeneration: A new approach to therapy. Neuropharmacology 2014, 76 Pt A, 169-174. [CrossRef] [PubMed]

4. Wolozin, B. Physiological protein aggregation run amuck: Stress granules and the genesis of neurodegenerative disease. Discov. Med. 2014, 17, 47-52. [PubMed]

5. Jackson, R.J.; Hellen, C.U.T.; Pestova, T.V. The mechanism of eukaryotic translation initiation and principles of its regulation. Nat. Rev. Mol. Cell Biol. 2010, 11, 113-127. [CrossRef] [PubMed]

6. Ohno, M. PERK as a hub of multiple pathogenic pathways leading to memory deficits and neurodegeneration in Alzheimer's disease. Brain Res. Bull. 2017. [CrossRef] [PubMed]

7. Baird, T.D.; Wek, R.C. Eukaryotic initiation factor 2 phosphorylation and translational control in metabolism. Adv. Nutr. 2012, 3, 307-321. [CrossRef] [PubMed]

8. Taniuchi, S.; Miyake, M.; Tsugawa, K.; Oyadomari, M.; Oyadomari, S. Integrated stress response of vertebrates is regulated by four eIF2 $\alpha$ kinases. Sci. Rep. 2016, 6, 32886. [CrossRef] [PubMed]

9. Donnelly, N.; Gorman, A.M.; Gupta, S.; Samali, A. The eIF2 $\alpha$ kinases: Their structures and functions. Cell. Mol. Life Sci. 2013, 70, 3493-3511. [CrossRef] [PubMed]

10. Raven, J.F.; Koromilas, A.E. PERK and PKR: Old kinases learn new tricks. Cell Cycle 2008, 7, 1146-1150. [CrossRef] [PubMed]

11. Wek, R.C.; Jiang, H.Y.; Anthony, T.G. Coping with stress: EIF2 kinases and translational control. Biochem. Soc. Trans. 2006, 34 Pt 1, 7-11. [CrossRef] [PubMed]

12. Costa-Mattioli, M.; Gobert, D.; Harding, H.; Herdy, B.; Azzi, M.; Bruno, M.; Bidinosti, M.; Ben Mamou, C.; Marcinkiewicz, E.; Yoshida, M.; et al. Translational control of hippocampal synaptic plasticity and memory by the eIF2 $\alpha$ kinase GCN2. Nature 2005, 436, 1166-1173. [CrossRef] [PubMed]

13. Lenox, A.R.; Bhootada, Y.; Gorbatyuk, O.; Fullard, R.; Gorbatyuk, M. Unfolded protein response is activated in aged retinas. Neurosci. Lett. 2015, 609, 30-35. [CrossRef] [PubMed]

14. Ill-Raga, G.; Tajes, M.; Busquets-García, A.; Ramos-Fernández, E.; Vargas, L.M.; Bosch-Morató, M.; Guivernau, B.; Valls-Comamala, V.; Eraso-Pichot, A.; Guix, F.X.; et al. Physiological control of nitric oxide in neuronal BACE1 translation by heme-regulated eIF2 $\alpha$ kinase HRI induces synaptogenesis. Antioxid. Redox Signal. 2015, 22, 1295-1307. [CrossRef] [PubMed] 
15. Ramos-Fernández, E.; Tajes, M.; Ill-Raga, G.; Vargas, L.; Busquets-García, A.; Bosch-Morató, M.; Guivernau, B.; Valls-Comamala, V.; Gomis, M.; Grau, C.; et al. Glutamatergic stimulation induces GluN2B translation by the nitric oxide-heme-regulated eIF2 $\alpha$ kinase in cortical neurons. Oncotarget 2016, 7, 58876-58892. [CrossRef] [PubMed]

16. Schmitt, E.; Naveau, M.; Mechulam, Y. Eukaryotic and archaeal translation initiation factor 2: A heterotrimeric tRNA carrier. FEBS Lett. 2010, 584, 405-412. [CrossRef] [PubMed]

17. DuRose, J.B.; Scheuner, D.; Kaufman, R.J.; Rothblum, L.I.; Niwa, M. Phosphorylation of eukaryotic translation initiation factor $2 \alpha$ coordinates rRNA transcription and translation inhibition during endoplasmic reticulum stress. Mol. Cell. Biol. 2009, 29, 4295-4307. [CrossRef] [PubMed]

18. Lu, P.D.; Harding, H.P.; Ron, D. Translation reinitiation at alternative open reading frames regulates gene expression in an integrated stress response. J. Cell Biol. 2004, 167, 27-33. [CrossRef] [PubMed]

19. Vattem, K.M.; Wek, R.C. Reinitiation involving upstream ORFs regulates ATF4 mRNA translation in mammalian cells. Proc. Natl. Acad. Sci. USA 2004, 101, 11269-11274. [CrossRef] [PubMed]

20. Novoa, I.; Zeng, H.; Harding, H.P.; Ron, D. Feedback inhibition of the unfolded protein response by GADD34-mediated dephosphorylation of eIF2 $\alpha$. J. Cell Biol. 2001, 153, 1011-1022. [CrossRef] [PubMed]

21. Dalet, A.; Argüello, R.J.; Combes, A.; Spinelli, L.; Jaeger, S.; Fallet, M.; Vu Manh, T.P.; Mendes, A.; Perego, J.; Reverendo, M.; et al. Protein synthesis inhibition and GADD34 control IFN- $\beta$ heterogeneous expression in response to dsRNA. EMBO J. 2017, 36, 761-782. [CrossRef] [PubMed]

22. Gentz, S.H.; Bertollo, C.M.; Souza-Fagundes, E.M.; da Silva, A.M. Implication of eIF2 $\alpha$ kinase GCN2 in induction of apoptosis and endoplasmic reticulum stress-responsive genes by sodium salicylate. J. Pharm. Pharmacol. 2013, 65, 430-440. [CrossRef] [PubMed]

23. Bellato, H.M.; Hajj, G.N. Translational control by eIF2 $\alpha$ in neurons: Beyond the stress response. Cytoskeleton 2016, 73, 551-565. [CrossRef] [PubMed]

24. Trinh, M.A.; Klann, E. Translational control by eIF2 $\alpha$ kinases in long-lasting synaptic plasticity and long-term memory. Neurobiol. Learn. Mem. 2013, 105, 93-99. [CrossRef] [PubMed]

25. Sidrauski, C.; Acosta-Alvear, D.; Khoutorsky, A.; Vedantham, P.; Hearn, B.R.; Li, H.; Gamache, K.; Gallagher, C.M.; Ang, K.K.; Wilson, C.; et al. Pharmacological brake-release of mRNA translation enhances cognitive memory. eLife 2013, 2, e00498. [CrossRef] [PubMed]

26. Costa-Mattioli, M.; Gobert, D.; Stern, E.; Gamache, K.; Colina, R.; Cuello, C.; Sossin, W.; Kaufman, R.; Pelletier, J.; Rosenblum, K.; et al. eIF2 $\alpha$ phosphorylation bidirectionally regulates the switch from short- to long-term synaptic plasticity and memory. Cell 2007, 129, 195-206. [CrossRef] [PubMed]

27. Costa-Mattioli, M.; Sossin, W.S.; Klann, E.; Sonenberg, N. Translational control of long-lasting synaptic plasticity and memory. Neuron 2009, 61, 10-26. [CrossRef] [PubMed]

28. Di Prisco, G.V.; Huang, W.; Buffington, S.A.; Hsu, C.C.; Bonnen, P.E.; Placzek, A.N.; Sidrauski, C.; Krnjević, K.; Kaufman, R.J.; Walter, P.; et al. Translational control of mGluR-dependent long-term depression and object-place learning by eIF2 $\alpha$. Nat. Neurosci. 2014, 17, 1073-1082. [CrossRef] [PubMed]

29. Jiang, Z.; Belforte, J.E.; Lu, Y.; Yabe, Y.; Pickel, J.; Smith, C.B.; Je, H.S.; Lu, B.; Nakazawa, K. eIF2 $\alpha$ phosphorylation-dependent translation in CA1 pyramidal cells impairs hippocampal memory consolidation without affecting general translation. J. Neurosci. 2010, 30, 2582-2594. [CrossRef] [PubMed]

30. O'Connor, T.; Sadleir, K.R.; Maus, E.; Velliquette, R.A.; Zhao, J.; Cole, S.L.; Eimer, W.A.; Hitt, B.; Bembinster, L.A.; Lammich, S.; et al. Phosphorylation of the translation initiation factor eIF2 $\alpha$ increases BACE1 levels and promotes amyloidogenesis. Neuron 2008, 60, 988-1009. [CrossRef] [PubMed]

31. Ma, T.; Trinh, M.A.; Wexler, A.J.; Bourbon, C.; Gatti, E.; Pierre, P.; Cavener, D.R.; Klann, E. Suppression of eIF2 $\alpha$ kinases alleviates Alzheimer's disease-related plasticity and memory deficits. Nat. Neurosci. 2013, 16, 1299-1305. [CrossRef] [PubMed]

32. Biever, A.; Boubaker-Vitre, J.; Cutando, L.; Gracia-Rubio, I.; Costa-Mattioli, M.; Puighermanal, E.; Valjent, E. Repeated exposure to D-amphetamine decreases global protein synthesis and regulates the translation of a subset of mRNAs in the striatum. Front. Mol. Neurosci. 2017, 9, 165. [CrossRef] [PubMed]

33. Jousse, C.; Bruhat, A.; Carraro, V.; Urano, F.; Ferrara, M.; Ron, D.; Fafournoux, P. Inhibition of CHOP translation by a peptide encoded by an open reading frame localized in the chop 5'-UTR. Nucleic Acids Res. 2001, 29, 4341-4351. [CrossRef] [PubMed] 
34. Chua, J.J.; Schob, C.; Rehbein, M.; Gkogkas, C.G.; Richter, D.; Kindler, S. Synthesis of two SAPAP3 isoforms from a single mRNA is mediated via alternative translational initiation. Sci. Rep. 2012, 2, 484. [CrossRef] [PubMed]

35. Studtmann, K.; Olschläger-Schütt, J.; Buck, F.; Richter, D.; Sala, C.; Bockmann, J.; Kindler, S.; Kreienkamp, H.J. A non-canonical initiation site is required for efficient translation of the dendritically localized Shank1 mRNA. PLoS ONE 2014, 9, e88518. [CrossRef] [PubMed]

36. Jakobson, M.; Jakobson, M.; Llano, O.; Palgi, J.; Arumäe, U. Multiple mechanisms repress N-Bak mRNA translation in the healthy and apoptotic neurons. Cell Death Dis. 2013, 4, e777. [CrossRef] [PubMed]

37. Bal, N.V.; Susorov, D.; Chesnokova, E.; Kasianov, A.; Mikhailova, T.; Alkalaeva, E.; Balaban, P.M.; Kolosov, P. Upstream open reading frames located in the leader of protein kinase $\mathrm{M} \zeta$ mRNA regulate its translation. Front. Mol. Neurosci. 2016, 9, 103. [CrossRef] [PubMed]

38. Ma, Y.; Hendershot, L.M. Delineation of a negative feedback regulatory loop that controls protein translation during endoplasmic reticulum stress. J. Biol. Chem. 2003, 278, 34864-34873. [CrossRef] [PubMed]

39. Bartsch, D.; Ghirardi, M.; Skehel, P.A.; Karl, K.A.; Herder, S.P.; Chen, M.; Bailey, C.H.; Kandel, E.R. Aplysia CREB2 represses long-term facilitation: Relief of repression converts transient facilitation into long-term functional and structural change. Cell 1995, 83, 979-992. [CrossRef]

40. Chen, A.; Muzzio, I.A.; Malleret, G.; Bartsch, D.; Verbitsky, M.; Pavlidis, P.; Yonan, A.L.; Vronskaya, S.; Grody, M.B.; Cepeda, I.; et al. Inducible enhancement of memory storage and synaptic plasticity in transgenic mice expressing an inhibitor of ATF4 (CREB-2) and C/EBP proteins. Neuron 2003, 39, 655-669. [CrossRef]

41. Harding, H.P.; Novoa, I.; Zhang, Y.; Zeng, H.; Wek, R.; Schapira, M.; Ron, D. Regulated translation initiation controls stress-induced gene expression in mammalian cells. Mol. Cell 2000, 6, 1099-1108. [CrossRef]

42. Marciniak, S.J.; Yun, C.Y.; Oyadomari, S.; Novoa, I.; Zhang, Y.; Jungreis, R.; Nagata, K.; Harding, H.P.; Ron, D. $\mathrm{CHOP}$ induces death by promoting protein synthesis and oxidation in the stressed endoplasmic reticulum. Genes Dev. 2004, 18, 3066-3077. [CrossRef] [PubMed]

43. Sulzer, D.; Sonders, M.S.; Poulsen, N.W.; Galli, A. Mechanisms of neurotransmitter release by amphetamines: A review. Prog. Neurobiol. 2005, 75, 406-433. [CrossRef] [PubMed]

44. Paschen, W.; Hayashi, T.; Saito, A.; Chan, P.H. GADD34 protein levels increase after transient ischemia in the cortex but not in the CA1 subfield: Implications for post-ischemic recovery of protein synthesis in ischemia-resistant cells. J. Neurochem. 2004, 90, 694-701. [CrossRef] [PubMed]

45. Chambers, J.E.; Dalton, L.E.; Clarke, H.J.; Malzer, E.; Dominicus, C.S.; Patel, V.; Moorhead, G.; Ron, D.; Marciniak, S.J. Actin dynamics tune the integrated stress response by regulating eukaryotic initiation factor $2 \alpha$ dephosphorylation. eLife 2015, 4, e04872. [CrossRef] [PubMed]

46. Chen, R.; Rato, C.; Yan, Y.; Crespillo-Casado, A.; Clarke, H.J.; Harding, H.P.; Marciniak, S.J.; Read, R.J.; Ron, D. G-actin provides substrate-specificity to eukaryotic initiation factor $2 \alpha$ holophosphatases. eLife 2015, 4, e04871. [CrossRef] [PubMed]

47. Lee, Y.Y.; Cevallos, R.C.; Jan, E. An upstream open reading frame regulates translation of GADD34 during cellular stresses that induce eIF2 $\alpha$ phosphorylation. J. Biol. Chem. 2009, 284, 6661-6673. [CrossRef] [PubMed]

48. Young, S.K.; Willy, J.A.; Wu, C.; Sachs, M.S.; Wek, R.C. Ribosome reinitiation directs gene-specific translation and regulates the integrated stress response. J. Biol. Chem. 2015, 290, 28257-28271. [CrossRef] [PubMed]

49. Jin, K.; Mao, X.O.; Eshoo, M.W.; del Rio, G.; Rao, R.; Chen, D.; Simon, R.P.; Greenberg, D.A. cDNA microarray analysis of changes in gene expression induced by neuronal hypoxia in vitro. Neurochem. Res. 2002, 27, 1105-1112. [CrossRef] [PubMed]

50. Méchaly, I.; Bourane, S.; Piquemal, D.; Al-Jumaily, M.; Ventéo, S.; Puech, S.; Scamps, F.; Valmier, J.; Carroll, P. Gene profiling during development and after a peripheral nerve traumatism reveals genes specifically induced by injury in dorsal root ganglia. Mol. Cell. Neurosci. 2006, 32, 217-229. [CrossRef] [PubMed]

51. Oyadomari, S.; Mori, M. Roles of CHOP/GADD153 in endoplasmic reticulum stress. Cell Death Differ. 2004, 11, 381-389. [CrossRef] [PubMed]

52. Ito, Y.; Yamada, M.; Tanaka, H.; Aida, K.; Tsuruma, K.; Shimazawa, M.; Hozumi, I.; Inuzuka, T.; Takahashi, H.; Hara, H. Involvement of CHOP, an ER-stress apoptotic mediator, in both human sporadic ALS and ALS model mice. Neurobiol. Dis. 2009, 36, 470-476. [CrossRef] [PubMed]

53. Papouin, T.; Ladépêche, L.; Ruel, J.; Sacchi, S.; Labasque, M.; Hanini, M.; Groc, L.; Pollegioni, L.; Mothet, J.P.; Oliet, S.H. Synaptic and extrasynaptic NMDA receptors are gated by different endogenous coagonists. Cell 2012, 150, 633-646. [CrossRef] [PubMed] 
54. Peng, Y.; Zhao, J.; Gu, Q.H.; Chen, R.Q.; Xu, Z.; Yan, J.Z.; Wang, S.H.; Liu, S.Y.; Chen, Z.; Lu, W. Distinct trafficking and expression mechanisms underlie LTP and LTD of NMDA receptor-mediated synaptic responses. Hippocampus 2010, 20, 646-658. [CrossRef] [PubMed]

55. Neyman, S.; Manahan-Vaughan, D. Metabotropic glutamate receptor 1 (mGluR1) and 5 (mGluR5) regulate late phases of LTP and LTD in the hippocampal CA1 region in vitro. Eur. J. Neurosci. 2008, 27, 1345-1352. [CrossRef] [PubMed]

56. Huber, K.M.; Kayser, M.S.; Bear, M.F. Role for rapid dendritic protein synthesis in hippocampal mGluR-dependent long-term depression. Science 2000, 288, 1254-1257. [CrossRef] [PubMed]

57. Zhu, P.J.; Huang, W.; Kalikulov, D.; Yoo, J.W.; Placzek, A.N.; Stoica, L.; Zhou, H.; Bell, J.C.; Friedlander, M.J.; Krnjević, K.; et al. Suppression of PKR promotes network excitability and enhanced cognition by interferon- $\gamma$-mediated disinhibition. Cell 2011, 147, 1384-1396. [CrossRef] [PubMed]

58. Nadif Kasri, N.; Nakano-Kobayashi, A.; Malinow, R.; Li, B.; Van Aelst, L. The Rho-linked mental retardation protein oligophrenin-1 controls synapse maturation and plasticity by stabilizing AMPA receptors. Genes Dev. 2009, 23, 1289-1302. [CrossRef] [PubMed]

59. Welch, J.M.; Lu, J.; Rodriguiz, R.M.; Trotta, N.C.; Peca, J.; Ding, J.D.; Feliciano, C.; Chen, M.; Adams, J.P.; Luo, J.; et al. Cortico-striatal synaptic defects and OCD-like behaviours in Sapap3-mutant mice. Nature 2007, 448, 894-900. [CrossRef] [PubMed]

60. Züchner, S.; Wendland, J.R.; Ashley-Koch, A.E.; Collins, A.L.; Tran-Viet, K.N.; Quinn, K.; Timpano, K.C.; Cuccaro, M.L.; Pericak-Vance, M.A.; Steffens, D.C.; et al. Multiple rare SAPAP3 missense variants in trichotillomania and OCD. Mol. Psychiatry 2009, 14, 6-9. [CrossRef] [PubMed]

61. Jakobson, M.; Lintulahti, A.; Arumäe, U. mRNA for N-Bak, a neuron-specific BH3-only splice isoform of Bak, escapes nonsense-mediated decay and is translationally repressed in the neurons. Cell Death Dis. 2012, 3, e269. [CrossRef] [PubMed]

62. Uo, T.; Kinoshita, Y.; Morrison, R.S. Neurons exclusively express N-Bak, a BH3 domain-only Bak isoform that promotes neuronal apoptosis. J. Biol. Chem. 2005, 280, 9065-9073. [CrossRef] [PubMed]

63. Lee, H.C.; Oh, N.; Cho, H.; Choe, J.; Kim, Y.K. Nonsense-mediated translational repression involves exon junction complex downstream of premature translation termination codon. FEBS Lett. 2010, 584, 795-800. [CrossRef] [PubMed]

64. Newton, A.C. Protein kinase C: Structural and spatial regulation by phosphorylation, cofactors, and macromolecular interactions. Chem. Rev. 2001, 101, 2353-2364. [CrossRef] [PubMed]

65. Pu, Y.; Peach, M.L.; Garfield, S.H.; Wincovitch, S.; Marquez, V.E.; Blumberg, P.M. Effects on ligand interaction and membrane translocation of the positively charged arginine residues situated along the $\mathrm{C} 1$ domain binding cleft in the atypical protein kinase C isoforms. J. Biol. Chem. 2006, 281, 33773-33788. [CrossRef] [PubMed]

66. Tobias, I.S.; Kaulich, M.; Kim, P.K.; Simon, N.; Jacinto, E.; Dowdy, S.F.; King, C.C.; Newton, A.C. Protein kinase $C \zeta$ exhibits constitutive phosphorylation and phosphatidylinositol-3,4,5-triphosphate-independent regulation. Biochem. J. 2016, 473, 509-523. [CrossRef] [PubMed]

67. Graybill, C.; Wee, B.; Atwood, S.X.; Prehoda, K.E. Partitioning-defective protein 6 (Par-6) activates atypical protein kinase C (aPKC) by pseudosubstrate displacement. J. Biol. Chem. 2012, 287, 21003-21011. [CrossRef] [PubMed]

68. Tsai, L.C.; Xie, L.; Dore, K.; Xie, L.; Del Rio, J.C.; King, C.C.; Martinez-Ariza, G.; Hulme, C.; Malinow, R.; Bourne, P.E.; et al. Zeta inhibitory peptide disrupts electrostatic interactions that maintain atypical protein kinase $C$ in its active conformation on the scaffold p62. J. Biol. Chem. 2015, 290, 21845-21856. [CrossRef] [PubMed]

69. Hernandez, A.I.; Blace, N.; Crary, J.F.; Serrano, P.A.; Leitges, M.; Libien, J.M.; Weinstein, G.; Tcherapanov, A.; Sacktor, T.C. Protein kinase Mz synthesis from a brain mRNA encoding an independent protein kinase $\mathrm{Cz}$ catalytic domain. Implications for the molecular mechanism of memory. J. Biol. Chem. 2003, 278, 40305-40316. [CrossRef] [PubMed]

70. Muslimov, I.A.; Nimmrich, V.; Hernandez, A.I.; Tcherepanov, A.; Sacktor, T.C.; Tiedge, H. Dendritic transport and localization of protein kinase Mzeta mRNA: Implications for molecular memory consolidation. J. Biol. Chem. 2004, 279, 52613-52622. [CrossRef] [PubMed]

71. Hernández, A.I.; Oxberry, W.C.; Crary, J.F.; Mirra, S.S.; Sacktor, T.C. Cellular and subcellular localization of PKMC. Philos. Trans. R. Soc. Lond. B Biol. Sci. 2013, 369, 20130140. [CrossRef] [PubMed] 
72. Pastalkova, E.; Serrano, P.; Pinkhasova, D.; Wallace, E.; Fenton, A.A.; Sacktor, T.C. Storage of spatial information by the maintenance mechanism of LTP. Science 2006, 313, 1141-1144. [CrossRef] [PubMed]

73. Shema, R.; Sacktor, T.C.; Dudai, Y. Rapid erasure of long-term memory associations in the cortex by an inhibitor of PKM zeta. Science 2007, 317, 951-953. [CrossRef] [PubMed]

74. Serrano, P.; Friedman, E.L.; Kenney, J.; Taubenfeld, S.M.; Zimmerman, J.M.; Hanna, J.; Alberini, C.; Kelley, A.E.; Maren, S.; Rudy, J.W.; et al. PKMzeta maintains spatial, instrumental, and classically conditioned long-term memories. PLoS Biol. 2008, 6, e318. [CrossRef] [PubMed]

75. Von Kraus, L.M.; Sacktor, T.C.; Francis, J.T. Erasing sensorimotor memories via PKMzeta inhibition. PLOS ONE 2010, 5, e11125. [CrossRef] [PubMed]

76. Sacktor, T.C. Memory maintenance by PKM $\zeta$-An evolutionary perspective. Mol. Brain 2012, 5, 31. [CrossRef] [PubMed]

77. Borodinova, A.A.; Zuzina, A.B.; Balaban, P.M. Role of atypical protein kinases in maintenance of long-term memory and synaptic plasticity. Biochemistry 2017, 82, 243-256. [CrossRef] [PubMed]

78. Balaban, P.M. Molecular mechanisms of memory modifications. Zhurnal Vysshei Nervnoi Deyatelnosti Imeni I.P. Pavlova 2017, 67, 131-140. [CrossRef]

79. Sacktor, T.C.; Osten, P.; Valsamis, H.; Jiang, X.; Naik, M.U.; Sublette, E. Persistent activation of the zeta isoform of protein kinase $\mathrm{C}$ in the maintenance of long-term potentiation. Proc. Natl. Acad. Sci. USA 1993, 90, 8342-8346. [CrossRef] [PubMed]

80. Osten, P.; Valsamis, L.; Harris, A.; Sacktor, T.C. Protein synthesis-dependent formation of protein kinase Mzeta in long-term potentiation. J. Neurosci. 1996, 16, 2444-2451. [PubMed]

81. Kelly, M.T.; Crary, J.F.; Sacktor, T.C. Regulation of protein kinase Mz synthesis by multiple kinases in long-term potentiation. J. Neurosci. 2007, 27, 3439-3444. [CrossRef] [PubMed]

82. Hsieh, C.; Tsokas, P.; Serrano, P.; Hernández, A.I.; Tian, D.; Cottrell, J.E.; Shouval, H.Z.; Fenton, A.A.; Sacktor, T.C. Persistent increased PKM $\zeta$ in long-term and remote spatial memory. Neurobiol. Learn. Mem. 2017, 138, 135-144. [CrossRef] [PubMed]

83. Balaban, P.M.; Roshchin, M.; Timoshenko, A.K.; Zuzina, A.B.; Lemak, M.; Ierusalimsky, V.N.; Aseyev, N.A.; Malyshev, A.Y. Homolog of protein kinase Mz maintains context aversive memory and underlying long-term facilitation in terrestrial snail Helix. Front. Cell. Neurosci. 2015, 9, 222. [CrossRef] [PubMed]

84. Ling, D.S.; Benardo, L.S.; Serrano, P.A.; Blace, N.; Kelly, M.T.; Crary, J.F.; Sacktor, T.C. Protein kinase Mzeta is necessary and sufficient for LTP maintenance. Nat. Neurosci. 2002, 5, 295-296. [CrossRef] [PubMed]

85. Dong, Z.; Han, H.; Li, H.; Bai, Y.; Wang, W.; Tu, M.; Peng, Y.; Zhou, L.; He, W.; Wu, X.; et al. Long-term potentiation decay and memory loss are mediated by AMPAR endocytosis. J. Clin. Investig. 2015, 125, 234-247. [CrossRef] [PubMed]

86. Wang, S.; Sheng, T.; Ren, S.; Tian, T.; Lu, W. Distinct roles of PKCı/ $\lambda$ and PKM $\zeta$ in the initiation and maintenance of hippocampal long-term potentiation and memory. Cell Rep. 2016, 16, 1954-1961. [CrossRef] [PubMed]

87. Drier, E.A.; Tello, M.K.; Cowan, M.; Wu, P.; Blace, N.; Sacktor, T.C.; Yin, J.C. Memory enhancement and formation by atypical PKM activity in Drosophila melanogaster. Nat. Neurosci. 2002, 5, 316-324. [CrossRef] [PubMed]

88. Shema, R.; Haramati, S.; Ron, S.; Hazvi, S.; Chen, A.; Sacktor, T.C.; Dudai, Y. Enhancement of consolidated long-term memory by overexpression of protein kinase Mzeta in the neocortex. Science 2011, 331, 1207-1210. [CrossRef] [PubMed]

89. Schuette, S.R.; Fernández-Fernández, D.; Lamla, T.; Rosenbrock, H.; Hobson, S. Overexpression of protein kinase $\mathrm{M} \zeta$ in the hippocampus enhances long-term potentiation and long-term contextual but not cued fear memory in rats. J. Neurosci. 2016, 36, 4313-4324. [CrossRef] [PubMed]

90. Ko, H.G.; Kim, J.I.; Sim, S.E.; Kim, T.; Yoo, J.; Choi, S.L.; Baek, S.H.; Yu, W.J.; Yoon, J.B.; Sacktor, T.C.; et al. The role of nuclear PKM $\zeta$ in memory maintenance. Neurobiol. Learn. Mem. 2016, 135, 50-56. [CrossRef] [PubMed]

91. Lin, D.; Pestova, T.V.; Hellen, C.U.; Tiedge, H. Translational control by a small RNA: Dendritic BC1 RNA targets the eukaryotic initiation factor 4A helicase mechanism. Mol. Cell. Biol. 2008, 28, 3008-3019. [CrossRef] [PubMed]

92. Westmark, P.R.; Westmark, C.J.; Wang, S.; Levenson, J.; O’Riordan, K.J.; Burger, C.; Malter, J.S. Pin1 and PKMzeta sequentially control dendritic protein synthesis. Sci. Signal. 2010, 3, ra18. [CrossRef] [PubMed] 
93. Yao, Y.; Kelly, M.T.; Sajikumar, S.; Serrano, P.; Tian, D.; Bergold, P.J.; Frey, J.U.; Sacktor, T.C. PKM zeta maintains late long-term potentiation by $N$-ethylmaleimide-sensitive factor/GluR2-dependent trafficking of postsynaptic AMPA receptors. J. Neurosci. 2008, 28, 7820-7827. [CrossRef] [PubMed]

94. Adzovic, L.; Domenici, L. Insulin induces phosphorylation of the AMPA receptor subunit GluR1, reversed by ZIP, and over-expression of Protein Kinase M zeta, reversed by amyloid beta. J. Neurochem. 2014, 131, 582-587. [CrossRef]

95. Santerre, J.L.; Rogow, J.A.; Kolitz, E.B.; Pal, R.; Landin, J.D.; Gigante, E.D.; Werner, D.F. Ethanol dose-dependently elicits opposing regulatory effects on hippocampal AMPA receptor GluA2 subunits through a zeta inhibitory peptide-sensitive kinase in adolescent and adult Sprague-Dawley rats. Neuroscience 2014, 280, 50-59. [CrossRef] [PubMed]

96. Shabashov, D.; Shohami, E.; Yaka, R. Inactivation of PKM $\zeta$ in the NAc shell abolished cocaine-conditioned reward. J. Mol. Neurosci. 2012, 47, 546-553. [CrossRef] [PubMed]

97. Yoshii, A.; Murata, Y.; Kim, J.; Zhang, C.; Shokat, K.M.; Constantine-Paton, M. TrkB and protein kinase M乙 regulate synaptic localization of PSD-95 in developing cortex. J. Neurosci. 2011, 31, 11894-11904. [CrossRef] [PubMed]

98. Leseux, L.; Laurent, G.; Laurent, C.; Rigo, M.; Blanc, A.; Olive, D.; Bezombes, C. PKC zeta mTOR pathway: A new target for rituximab therapy in follicular lymphoma. Blood 2008, 111, 285-291. [CrossRef] [PubMed]

99. Velazquez-Garcia, S.; Valle, S.; Rosa, T.C.; Takane, K.K.; Demirci, C.; Alvarez-Perez, J.C.; Mellado-Gil, J.M.; Ernst, S.; Scott, D.K.; Vasavada, R.C.; et al. Activation of protein kinase $C-\zeta$ in pancreatic $\beta$-cells in vivo improves glucose tolerance and induces $\beta$-cell expansion via mTOR activation. Diabetes 2011, 60, 2546-2559. [CrossRef] [PubMed]

100. Pöyry, T.A.A.; Kaminski, A.; Jackson, R.J. What determines whether mammalian ribosomes resume scanning after translation of a short upstream open reading frame? Genes Dev. 2004, 18, 62-75. [CrossRef] [PubMed]

101. Carrara, M.; Sigurdardottir, A.; Bertolotti, A. Decoding the selectivity of eIF $2 \alpha$ holophosphatases and PPP1R15A inhibitors. Nat. Struct. Mol. Biol. 2017, 24, 708-716. [CrossRef] [PubMed] 